\title{
Sex Differences in Microglia Activity within the Periaqueductal Gray of the Rat: A Potential Mechanism Driving the Dimorphic Effects of Morphine
}

\author{
-Hillary H. Doyle, Lori N. Eidson, David M. Sinkiewicz, and ${ }^{\circledR A n n e ~ Z . ~ M u r p h y ~}$ \\ Neuroscience Institute, Georgia State University, Atlanta, Georgia 30303
}

\begin{abstract}
Although morphine remains the primary drug prescribed for alleviation of severe or persistent pain, both preclinical and clinical studies have shown that females require two to three times more morphine than males to produce comparable levels of analgesia. In addition to binding to the neuronal $\mu$-opioid receptor, morphine binds to the innate immune receptor toll-like receptor 4 (TLR4) localized primarily on microglia. Morphine action at TLR4 initiates a neuroinflammatory response that directly opposes the analgesic effects of morphine. Here, we test the hypothesis that the attenuated response to morphine observed in females is the result of increased microglia activation in the periaqueductal gray (PAG), a central locus mediating the antinociceptive effects of morphine. We report that, whereas no overall sex differences in the density of microglia were noted within the PAG of male or female rats, microglia exhibited a more "activated" phenotype in females at baseline, with the degree of activation a significant predictor of morphine half-maximal antinociceptive dose $\left(\mathrm{ED}_{50}\right)$ values. Priming microglia with LPS induced greater microglia activation in the PAG of females compared with males and was accompanied by increased transcription levels of IL-1 $\beta$ and a significant rightward shift in the morphine dose-response curve. Blockade of morphine binding to PAG TLR4 with (+)-naloxone potentiated morphine antinociception significantly in females such that no sex differences in $\mathrm{ED}_{50}$ were observed. These results demonstrate that PAG microglia are sexually dimorphic in both basal and LPS-induced activation and contribute to the sexually dimorphic effects of morphine in the rat.
\end{abstract}

Key words: analgesia; microglia; morphine; nociception; pain; sex differences

Significance Statement

We demonstrate that periaqueductal gray (PAG) microglia contribute to the sexually dimorphic effects of morphine. Specifically, we report that increased activation of microglia in the PAG contributes to the attenuated response to morphine observed in females. Our data further implicate the innate immune receptor toll-like receptor 4 (TLR4) as an underlying mechanism mediating these effects and establish that TLR4 inhibition in the PAG of females reverses the sex differences in morphine responsiveness. These data suggest novel methods to improve current opioid-based pain management via inhibition of glial TLR4 and illustrate the necessity for sex-specific research and individualized treatment strategies for the management of pain in men and women.

\section{Introduction}

Opioid therapy remains a primary strategy for severe and chronic pain management, with 3-4\% of adults in the United States receiving long-term opioid therapy (Dowell et al., 2016); however,

Received Sept. 15, 2016; revised Jan. 30, 2017; accepted Feb. 6, 2017.

Author contributions: H.H.D., L.N.E., D.M.S., and A.Z.M. designed research; H.H.D., L.N.E., D.M.S., and A.Z.M. performed research; H.H.D. and A.Z.M. analyzed data; H.H.D. and A.Z.M. wrote the paper

This work was supported by the National Institutes of Health (Grant DA16272 to A.Z.M.) (-)-Morphine sulfate and (+)-naloxone were kindly provided by the National Institute on Drug Abuse drug supply program. We thank Lauren Hanus and Alyssa Bartlett for technical assistance.

The authors declare no competing financial interests.

Correspondence should be addressed to Anne Z. Murphy, Neuroscience Institute, Georgia State University, 100 Piedmont Ave, SE, Atlanta, GA 30303. E-mail: amurphy@gsu.edu.

DOI:10.1523/JNEUROSCI.2906-16.2017

Copyright $\odot 2017$ the authors $\quad 0270-6474 / 17 / 373202-13 \$ 15.00 / 0$ preclinical studies using a variety of acute and persistent pain assays have repeatedly demonstrated that morphine is more effective in males than in females (Dawson-Basoa and Gintzler, 1993; Mogil et al., 2000; Wang et al., 2006; Craft et al., 2008; Loyd et al., 2008b). Decreased analgesic efficacy is often countered with dose escalation, leading to increased risk of negative side effects associated with opiate consumption, including respiratory depression, tolerance, and overdose (Trescot et al., 2006).

Several exogenous opioids, including morphine, bind to the myeloid differentiation factor 2 (MD-2) coreceptor of the innate immune receptor toll-like receptor 4 (TLR4) (Hutchinson et al., 2010). TLR4 is located primarily on microglia (Lehnardt et al., 2002; Lehnardt et al., 2003; Jou et al., 2006; Marinelli et al., 2015) and activation of the MD2-TLR4 complex promotes the expression of pro-inflammatory and anti-inflammatory compounds including 
cytokines such as tumor necrosis factor-alpha (TNF $\alpha$ ), interleukins (IL-1 $\beta$, IL-6, IL-10), chemokines (CXCL3), and prostaglandin E2 (PGE2) (Bonizzi and Karin, 2004; Doyle and O'Neill, 2006; Hutchinson et al., 2008c; Hutchinson et al., 2010). Activation of TLR4 and the release of proinflammatory signaling molecules increases neuronal excitability via upregulation of the $\alpha$-amino-3hydroxy-5-methyl-4-isoxazolepropionic acid (AMPA) receptor (Ogoshi et al., 2005; Stellwagen et al., 2005), downregulation of glutamate transporter (Yan et al., 2014; Eidson et al., 2017), and decreased $\gamma$-aminobutyric acid $\left(\mathrm{GABA}_{\mathrm{A}}\right)$ receptor expression that together induce hyperalgesia. Therefore, morphine paradoxically reduces its analgesic efficacy through TLR4-mediated inflammation (Song and Zhao, 2001; Hutchinson et al., 2007; Hutchinson et al., 2010; Franchi et al., 2012; Li, 2012; Wang et al., 2012; Eidson and Murphy, 2013a, 2013b; Eidson et al., 2017).

The ventrolateral midbrain periaqueductal gray (vlPAG) is a critical neural locus mediating the antinociceptive effects of morphine (Morgan et al., 2005; Loyd et al., 2007). Direct PAG administration of morphine induces long-lasting analgesia, whereas identical administration of the opioid antagonist ( - )-naloxone or lesions of PAG $\mu$-opioid receptor (MOR) completely abolish the antinociceptive effects of systemic morphine (Loyd et al., 2008b). The antinociceptive effects of intra-PAG morphine are highly sex-dependent, such that in males, the half-maximal antinociceptive dose $\left(\mathrm{ED}_{50}\right)$ of morphine ranges from 1.2 to $1.6 \mu \mathrm{g} /$ $\mu \mathrm{l}$, whereas in females, $\mathrm{ED}_{50}$ values range from 16 to $>50 \mu \mathrm{g} / \mu \mathrm{l}$ (Krzanowska and Bodnar, 1999; Loyd et al., 2008b; Bobeck et al., 2009).

MD-2 is densely expressed within the PAG and administration of morphine activates PAG microglia, opposing the analgesic effects of morphine and inducing tolerance in a TLR4-dependent manner (Eidson and Murphy, 2013a, 2013b; Eidson et al., 2017). Similarly, blockade of PAG microglial activation in male rats via TLR4 inhibition potentiates morphine analgesia and suppresses the development of tolerance (Eidson and Murphy, 2013a; Eidson et al., 2017). Here, we test the hypothesis that the sexually dimorphic effects of morphine are due to sex differences in microglia activation in the PAG.

\section{Materials and Methods}

Subjects

Age-matched (60-90 d old) intact male and normally cycling female Sprague Dawley rats (Charles River Laboratories) were used. Animals were pair-housed with the same sex on a 12:12 h light/dark cycle (lights on at 08:00). Access to food and water was available ad libitum throughout the experiments except during behavioral testing. All studies were approved by the Institutional Animal Care and Use Committee at Georgia State University and were performed in compliance with Ethical Issues of the International Association for the Study of Pain and National Institutes of Health. All efforts were made to reduce the number of animals used in these experiments and to minimize pain and suffering.

\section{Vaginal cytology}

Vaginal lavages were performed daily beginning $7 \mathrm{~d}$ before testing to confirm that all female rats were cycling normally and to record cycle stage at the time of testing. Proestrus was identified as a predominance of nucleated epithelial cells and estrus was identified as a predominance of cornified epithelial cells. Diestrus 1 was differentiated from Diestrus 2 by the presence of leukocytes. Rats that appeared between phases were noted as being in the more advanced stage (Loyd et al., 2007).

\section{Experiment 1: influence of acute morphine administration on} PAG microglia expression and morphology

To determine whether morphine activation of microglia was sexually dimorphic, male and female rats received a single $\mathrm{ED}_{50}$ injection of (-)morphine sulfate (5 mg/kg; National Institute on Drug Abuse, Bethesda,
MD) or saline (1 mg/kg) subcutaneously and were killed by transcardial perfusion 15, 30, or 60 min after injection. An additional group of animals served as handled controls, resulting in a total of six to eight animals per sex per group for a total of 54 males and 48 females.

Immunohistochemistry. At the end of the experiment, animals were given a lethal dose of SomnaSol $(0.5-1.0 \mathrm{ml} / \mathrm{kg}$, i.p. $)$ and transcardially perfused with $200-250 \mathrm{ml}$ of $0.9 \%$ sodium chloride containing $2 \%$ sodium nitrite as a vasodilator, followed by $300 \mathrm{ml}$ of $4 \%$ paraformaldehyde in $0.1 \mathrm{M}$ potassium PBS (KPBS). Brains were postfixed in $4 \%$ paraformaldehyde and KPBS for $48 \mathrm{~h}$ and then placed in a 30\% sucrose solution and stored at $4^{\circ} \mathrm{C}$. Brains were sectioned coronally at $25 \mu \mathrm{m}$ with a Leica 2000R freezing microtome and stored free-floating in cryoprotectant-antifreeze solution at $-20^{\circ} \mathrm{C}$. A 1:6 series through the rostrocaudal axis of each brain was processed for ionized calcium binding adaptor molecule 1 (Iba-1) immunoreactivity using standard immunhistochemical techniques as described previously (Loyd and Murphy, 2006). Iba-1 was selected because it is specific to microglia and is constitutively expressed across all stages of activation, allowing for both qualitative and quantitative assessment in both healthy/uninjured animals as well as endotoxin- and morphine-treated animals. Briefly, sections were rinsed extensively in KPBS to remove cryoprotectant and then incubated in a rabbit anti-Iba-1 (WAKO Chemicals; $1: 10 \mathrm{~K}$ ) primary antibody solution in KPBS containing $1.0 \%$ Triton X-100 for $1 \mathrm{~h}$ at room temperature, followed by $72 \mathrm{~h}$ at $4^{\circ} \mathrm{C}$. After rinsing with KPBS, the tissue was incubated for $1 \mathrm{~h}$ in biotinylated donkey anti-rabbit IgG (Jackson Immunoresearch; 1:600), rinsed with KPBS, and incubated for $1 \mathrm{~h}$ in an avidin-biotin peroxidase complex (1:10; ABC Elite Kit; Vector Laboratories). After rinsing in KPBS and sodium acetate $(0.175 \mathrm{M}, \mathrm{pH} 6.5)$, microglia immunoreactivity was visualized as a black or purple reaction product using nickel sulfate intensified 3,3'-diaminobenzidine (DAB) solution $(2 \mathrm{mg} / 10 \mathrm{ml})$ containing $0.08 \%$ hydrogen peroxide in sodium acetate buffer. After incubation in DAB, tissue was rinsed in sodium acetate buffer followed by KPBS. Sections were then mounted out of KPBS onto gelatin-subbed slides, air-dried, and dehydrated in a series of graded alcohols. Tissue-mounted slides were then cleared in xylene and glass coverslipped using Permount mounting medium.

Densitometry and presentation. Levels of Iba- 1 immunoreactivity in the vlPAG were compared across sex and treatment groups using semiquantitative densitometry as described previously (Loyd et al., 2008b; Laprairie and Murphy, 2009; Eidson and Murphy, 2013a). Twelve-bit grayscale images were captured using a QImaging Retiga EXi CCD camera attached to a Nikon microscope and iVision Image analysis software (BioVision Technologies). The region of interest included sections through 6 representative levels of the rostrocaudal axis of the vlPAG (bregma $-6.72,-7.04,-7.64,-8.0,-8.30,-8.80$ ), with $6-12$ sections per brain as described previously (Loyd et al., 2007). Because the distribution of glial cells was bilaterally symmetrical in the vlPAG, sections were sampled unilaterally.

Morphological analysis of microglia subtype. Microglia morphology is highly representative of functional state (Karperien et al., 2013). Microglia were sampled as described above (2-3 representative sections of the caudal ventrolateral PAG (bregma -7.64 to -8.3 ) per animal) and classified into one of three principle morphological subtypes: "nonramified" cells, "intermediate" cells, and "ramified" cells. Nonramified cells were characterized as having a large circular or oval cell body that is either completely amoeboid in shape or with one or two thick primary processes and no secondary processes. Highly ramified "intermediate" cells were characterized as having many stout, thick processes arranged in bundles around a large cell body. "Intermediate" cells often have several thick primary processes extending a relatively short distance from the soma; each primary process often has many short secondary processes, giving these cells a "bushy" appearance, and are very darkly stained with Iba- 1 . In contrast to nonramified and intermediate cells, highly ramified cells have small, round cell bodies with many (generally four to 10) long, thin processes. The primary processes of highly ramified microglia have few secondary processes, extend a large distance from the soma, and are often lightly stained with Iba-1. Representative images of each cell type are provided in Figure 1. Nonramified and intermediate microglia are considered to be "active" or "reactive," whereas highly ramified mi- 


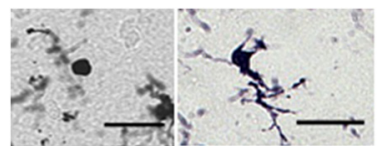

Non- Ramified

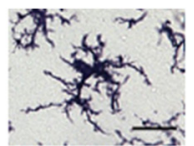

Intermediate

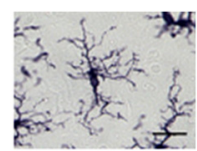

Ramified
Figure 1. Microglial subtypes. Representative images of the three classifications of microglia based on morphology are shown. "Nonramified": round/amoeboid activated microglia; "intermediate": reactive microglia with numerous thick processes; "ramified": microglia with thin long processes. Scale bars, $2 \mu \mathrm{m}$ in all images.

croglia with thin processes are considered to be quiescent (Frank et al., 2006; Bland et al., 2010; Colton and Wilcock, 2010; Kettenmann et al., 2011; Karperien et al., 2013; Lenz et al., 2013). Iba1-positive cells were counted only if the cell body and processes were completely visible within the image. Ambiguous cells with processes extending beyond the borders of the image, overlapping cells, and cells out of the plane of focus of the image were not counted.

Data analysis. Morphological cell counts were conducted using the ImageJ Cell Counter tool by three independent investigators blinded to treatment and sex of the animal. Total numbers of microglia were also determined to assess changes in microglia migration or proliferation. Morphological cell counts and total microglia number are presented as the mean \pm SEM. Statistical analyses were performed using SPSS software (version 21); data were analyzed using an ANOVA to determine the significant main effects of sex and treatment on microglia cell counts and morphology. Bonferroni's post hoc test was used to determine a priori specified specific group differences when a significant main effect was observed. $p \leq 0.05$ was considered statistically significant.

\section{Experiment 2: correlation between microglia activation and morphine $E D_{50}$}

To determine whether there was a relationship between microglia morphological subtype and morphine $\mathrm{ED}_{50}$ values, animals ( $n=15$ males, 8 females) were tested using our cumulative dosing paradigm (Morgan et al., 2006; Loyd et al., 2008b; Eidson and Murphy, 2013a; Eidson et al., 2017). Briefly, animals received an injection of morphine every $20 \mathrm{~min}$, resulting in cumulative doses of $1.8,3.2,5.6,8.0,10.0$, and $18 \mathrm{mg} / \mathrm{kg}$. Control animals received repeated saline injections ( $1 \mathrm{ml} / \mathrm{kg} ; \mathrm{s.c} ; n=6$ males, 7 females). Thermal nociception was assessed using the paw thermal stimulator 15 min after each injection (Hargreaves et al., 1988; Wang et al., 2006; Loyd et al., 2008a; Eidson and Murphy, 2013a). Briefly, for this test, the rat is placed in a clear Plexiglas box resting on an elevated glass plate maintained at $30^{\circ} \mathrm{C}$. A radiant beam of light is positioned under the hindpaw and the time for the rat to remove the paw from the thermal stimulus is electronically recorded as the paw withdrawal latency (PWL) in seconds. A maximal PWL of $20 \mathrm{~s}$ was used to prevent tissue damage due to repeated application of the noxious thermal stimulus. Animals were acclimated to the testing apparatus $30-60 \mathrm{~min} / \mathrm{d}$ for 3 consecutive days before the start of the experiment and on the day of testing. All behavioral testing took place between 12:00 and 17:00 (lights on at 08:00). Temperature of the thermal stimulus was recorded before and after each trial to maintain consistent recordings between groups and did not exceed $64^{\circ} \mathrm{C}$ throughout the course of the experiments. All testing was conducted blinded with respect to group assignment. To calculate $\mathrm{ED}_{50}$, PWL data were normalized using GraphPad Prism software such that each individual animal's baseline PWL score $=0 \%$ and $20 \mathrm{~s}=100 \%$. The normalized data were then plotted and $\mathrm{ED}_{50}$ was calculated as the point on the $x$-axis that corresponds to $50 \%$ maximal PWL (Morgan et al., 2006; Eidson and Murphy, 2013a; Eidson et al., 2017).

Immunohistochemistry. Within $60 \mathrm{~min}$ of the final morphine dose, animals were perfused and tissue was collected for immunohistochemical analyses. Microglia were categorized in the vlPAG as described above. To determine whether morphine's impact on glia morphology was limited to the PAG or if it represented a more centralized effect, microglia were also characterized by morphological type for the following brain regions: rostral ventromedial medulla (RVM; bregma - 11.2:-12.2; im- plicated in pain modulation), superior colliculus (SC; bregma -6.9 : -8.2; high MOR density but not implicated in pain), and substantia nigra (SN; bregma $-5.0:-5.3$; high levels of MOR and implicated in reward and addiction). The medial amygdala (MeA: bregma -2.4:-3.0) was also analyzed because this region has a high density of microglia, but is not implicated in pain and is devoid of MOR.

Data analysis and presentation. Morphine $\mathrm{ED}_{50}$ values were compared between males and females using Mann-Whitney $U$ test to confirm replication of previously observed sex differences (Loyd et al., 2008a, 2008b). Analysis of covariation between $\mathrm{ED}_{50}$ values and microglial morphological subtype were assessed for each sex using SPSS statistical software; $p \leq 0.05$ was considered significant.

\section{Experiment 3: influence of peripheral endotoxin LPS on microglia} response in the vIPAG

To determine whether sex differences in microglia activation are driven by morphine or reflected a global sex difference in activation, animals received an injection of the TLR4 agonist lipopolysaccharide (endotoxin LPS; $1 \mathrm{mg} / \mathrm{kg}$, i.p.; Sigma-Aldrich; $n=7$ males, 6 females) or equivolume saline ( $n=7$ males, 6 females). Comparable doses of peripheral LPS have been shown in male rats to increase the proinflammatory cytokine IL- $1 \beta$ mRNA in the brain (Buttini and Boddeke, 1995; Nguyen et al., 1998; Quan et al., 1998; Quan et al., 1999) and alter microglia morphology (Buttini et al., 1996). LPS-induced febrile responses were monitored using Thermocron iButtons (Maxim Integrated; model DS1921G), implanted into the abdominal cavity $7-10 \mathrm{~d}$ before testing. Body temperature was recorded in $30 \mathrm{~min}$ intervals beginning $6 \mathrm{~h}$ before LPS. Animals were killed and transcardially perfused $6 \mathrm{~h}$ after LPS administration, when central cytokine mRNA levels peak (Nakamura et al., 1999; Turrin et al., 2001; Qin et al., 2007; Czerniawski and Guzowski, 2014). Tissue was collected and processed for visualization of microglia (Iba-1) as described above. Iba-1 levels were analyzed for the PAG, RVM, SC, SN, and MeA. A subset of animals were killed by decapitation and their brains flash frozen for determination of cytokine levels using $\mathrm{qPCR}$ as described previously (Eidson et al., 2017).

Examination and presentation of immunomodulatory cytokines using $q P C R$. Flash-frozen brains were sectioned at $300 \mu \mathrm{m}$ on a cryostat (Leica) and mounted onto slides. One-millimeter bilateral micropunches were taken from 6 levels of the vlPAG (bregma $-6.72,-7.04,-7.64,-8.0$, $-8.30,-8.80$ ) and RNA was extracted with TRIzol (Life Technologies; 15596026) using standard procedures, followed by the addition of Glycoblue (Life Technologies; AM5916) for visualization. Concentrations of RNA (ng/ $\mu \mathrm{l})$ were calculated using a NanoDrop ND-1000 Spectrophotometer (Version 3.8, Thermo Fisher). After RNA extraction, RNA was diluted to a standard concentration and converted to cDNA using an AMV First-Strand Synthesis Kit (Invitrogen). PCR was performed using FastStart Essential DNA Green MasterMix (Roche) and analyzed using a Roche LightCycler 96 and accompanying software (version 1.1.0.1320, 2011 Roche). Data are presented as the normalized ratio of the target gene, with corrected amplification efficiency, relative to the GAPDH control gene. Primer sequences can be found in Table 1 .

Data analysis. The impact of sex and treatment on microglia morphology and cytokine mRNA levels were analyzed using an ANOVA, with Bonferroni post hoc analysis where appropriate. Differences between males and females were compared using independent $t$ tests when $k=2$. Body temperature data were analyzed for significant main effects of sex and treatment across time using a mixed-model ANOVA with Greenhouse-Geisser correction. Body temperature data are presented as the difference between saline-treated groups at $1 \mathrm{~h}$ intervals after LPS. Density, morphology, and PCR data are presented as $\Delta C \mathrm{q}$ means \pm SEM; $p \leq 0.05$ was considered significant.

Experiment 4: effect of TLR4 manipulation on morphine analgesia Intra-vlPAG cannulae implantation. To determine whether PAG TLR4 activation or inhibition impacted morphine analgesia, animals were anesthetized to a deep surgical plane with $5 \%$ isoflurane (maintained at $2-5 \%$ isoflurane throughout surgery; Henry Schein Animal Health) and bilateral guide cannulae (22 gauge; Plastics One) aimed at the vlPAG (anterior-posterior: $1.7 \mathrm{~mm}$; mediolateral: $\pm 0.6 \mathrm{~mm}$; dorsoventral: 
Table 1. Primer sequences for $\mathrm{qPCR}$

\begin{tabular}{ll}
\hline GAPDH & \\
Forward & GAG GTG ACC GCA TCT TCT TG \\
Reverse & CCG ACC TTC ACC ATC TTG TC \\
IL-1 $\beta$ & \\
Forward \\
Reverse & CCC TGA AGG ATG TGA TCA TTG \\
IL-6 & GGC AAA GGG TTT CTC CAC TT \\
Forward & \\
Reverse & AAG ACC CAA GCA CCT TCT TT \\
IL-10 & AGA CAG CAC GAG GCA TTT TT \\
Forward & \\
Reverse & TGT ACC TTA TCT ACT CCC AGG TTC TCT \\
TNF & GTG TGG GTG AGG AGC ACG TA \\
Forward & \\
Reverse & TGT ACC TTA TCT ACT CCC AGG TTC TCT \\
TLR4 & GTG TGG GTG AGG AGC ACG TA \\
Forward & \\
Reverse & TCC CTG CAT AGA GGT ACT TC \\
\hline
\end{tabular}

Sequences are listed for GAPDH (control gene) and the proinflammatory cytokines IL-1 $\beta, \mathrm{IL}-6, \mathrm{IL}-10$, and TNF, as well as the immune receptor TLR4.

$-5.0 \mathrm{~mm}$ from lambda) were implanted stereotaxically as described previously (Loyd et al., 2008b; Eidson and Murphy, 2013a). Animals were allowed to recover a minimum of $10 \mathrm{~d}$ after cannula implantation before behavioral testing. Injection cannulae were inserted into guide cannulae once a day for $3 \mathrm{~d}$ before testing to acclimate the animals to the injection procedure and to maintain cannulae patency. Animals with blocked cannula were retained as no-injection controls. No significant differences were observed between noninjected animals ( $n=2$ males, 5 females) and those animals receiving intra-PAG saline, so these groups were collapsed (data not shown).

Experiment 4.1: effects of TLR4 agonism on morphine analgesia. On the day of testing, male and female rats received a single intra-PAG injection of LPS ( $5.0 \mu \mathrm{g} / 0.5 \mu \mathrm{l} / \mathrm{side}$; Sigma-Aldrich) or saline ( $0.5 \mu \mathrm{l} / \mathrm{side})$ into the PAG. This dose has been shown previously to increase glial activation and cytokine expression (Castaño et al., 2002; Hernández-Romero et al., 2008; Eidson and Murphy, 2013a). One hour later, morphine $\mathrm{ED}_{50}$ values were determined using the cumulative dosing paradigm described in Experiment 2. A total of 4 treatment groups were generated: Saline + Saline ( $n=5$ males, 5 females), LPS + Saline ( $n=5$ males, 5 females), Saline + Morphine ( $n=8$ males, 11 females), and LPS + Morphine $(n=$ 7 males, 8 females).

Experiment 4.2: effects of TLR4 antagonism on morphine analgesia. On the day of testing, animals received a single intra-PAG injection of $(+)$ naloxone $(5.0 \mu \mathrm{g} / 0.5 \mu \mathrm{l} / \mathrm{side}$; NIDA) or saline $(0.5 \mu \mathrm{l} / \mathrm{side})$ and, $1 \mathrm{~h}$ later, morphine $\mathrm{ED}_{50}$ values were determined as described above. This dose was chosen based on our previous experiments demonstrating inhibition of PAG microglia (Eidson and Murphy, 2013a). A total of 4 treatment groups were generated: Saline + Saline ( $n=5$ males, 5 females), Naloxone + Saline $(n=5$ males, 5 females $)$, Saline + Morphine $(n=8$ males, 11 females), and Naloxone + Morphine ( $n=7$ males, 9 females).

Data analysis and presentation. At the end of the experiment, brains were removed, flash frozen, and sectioned at $25 \mu \mathrm{m}$ with a Leica CM3050S cryostat. Sections from the injection site were mounted on to slides, Nissl stained, coverslipped, and cannulae placement verified using a Nikon microscope $(10 \times$ magnification). Animals with bilateral cannulae located outside of the vlPAG (e.g., in the aqueduct or deep mesencephalic nucleus) were considered "cannulae misses" and were analyzed for determination of site specificity.

Half-maximal antinociceptive effect $\left(\mathrm{ED}_{50}\right)$ and $95 \%$ confidence intervals were calculated from dose-response curves generated using GraphPad Prism software as described above. Repeated-measures ANOVA was used to assess for significant treatment effects, with Bonferroni's post hoc tests where appropriate. Cannula misses were compared with "hits" using a two-tailed Wilcoxon signed-rank test. Values of $p \leq 0.05$ were considered statistically significant.

\section{Results}

Experiment 1: sex, but not morphine treatment, affects microglia activation in the vlPAG

Male and female rats were administered morphine or saline and microglia were examined immunohistochemically within the caudal vlPAG at 15, 30, and $60 \mathrm{~min}$ after injection. A separate group of rats served as handled controls. No significant effect of time postinjection was noted in microglia morphology for either the saline- or morphine-treated groups, so these data are collapsed across time. In addition, no significant differences were observed in total microglia cell counts in the PAG regardless of $\operatorname{sex}\left(F_{(1,68)}=0.013, p=0.91\right)$ or treatment $\left(F_{(1,68)}=0.13, p=\right.$ 0.720 ) (Fig. 2a).

Overall, females had significantly more nonramified and intermediate type microglia in the vlPAG that was independent of treatment $\left(F_{(1,76)}=13.10, p=0.01\right.$; Fig. $\left.2 b\right)$. We next determined whether the observed sex difference in percentage of activated microglia was specific for a morphological subtype (nonramified, intermediate or ramified; Fig. 1). The percentage of both nonramified $(t=3.10, p<0.001)$ and intermediate $(t=2.17, p=$ $0.03)$ microglia was significantly higher in females than in males (Fig. 2c). Females also had significantly fewer ramified microglia than males $(t=3.90, p<0.001)$. Together, these data indicate that, although there are no sex differences in the overall number of vlPAG microglia, the ratio of nonramified and intermediate to ramified microglia are significantly greater in females than males regardless of treatment.

\section{Experiment 2: microglial activation in the PAG correlates with morphine $\mathrm{ED}_{50}$}

PAG or spinal cord activation of microglia has been shown to oppose morphine analgesia (Watkins et al., 2005; Hutchinson et al., 2010; Eidson and Murphy, 2013a, 2013b); therefore, we next examined the degree of association between morphine $\mathrm{ED}_{50}$ values and PAG microglia morphology for males and females. Animals were administered cumulative doses of morphine and killed within $60 \mathrm{~min}$ of the final injection of morphine; microglia morphology was determined immunohistochemically. Consistent with our previous studies (Loyd et al., 2008a; Loyd et al., 2008b), ED $_{50}$ values were significantly higher in females than males (female, 8.69 vs male, $6.01 \mathrm{mg} / \mathrm{kg} ; \mathrm{U}=30.5, p=0.028)$ and no relationship was observed between $\mathrm{ED}_{50}$ and female estrous cycle $(r=0.19, p=$ $0.19)$. Morphine $\mathrm{ED}_{50}$ values were significantly correlated with the percentage of nonramified and intermediate microglia, morphologies typical of "activated" microglia, in the vlPAG in both males $(r=0.58, p=0.02)$ and females $(r=0.68$, $p=0.047$; Fig. $3 a$ ). Further analysis by microglia morphological subtype showed no significant correlation for nonramified microglia and morphine $\mathrm{ED}_{50}$ in males $(r=0.47, p=0.051)$ or females $(r=0.32, p=0.24)$. Intermediate microglia correlated significantly with $\mathrm{ED}_{50}$ in females $(r=0.679, p=0.047)$, but not males $(r=0.316, p=0.15)$, and ramified microglia negatively correlated with $\mathrm{ED}_{50}$ in both males $(r=-0.58, p=$ $0.02)$ and females $(r=-0.68, p=0.047$; Fig. $3 b)$. Together, these data show sex-specific positive correlations between morphine $\mathrm{ED}_{50}$ and percentage of activated microglia and reciprocal negative correlations with morphine $\mathrm{ED}_{50}$ and ramified microglia such that, as the percentage of ramified microglia decreases, morphine $\mathrm{ED}_{50}$ increases (i.e., morphine is less efficacious).

We next determined whether the relationship between microglia morphology and morphine $\mathrm{ED}_{50}$ values was specific to 
a

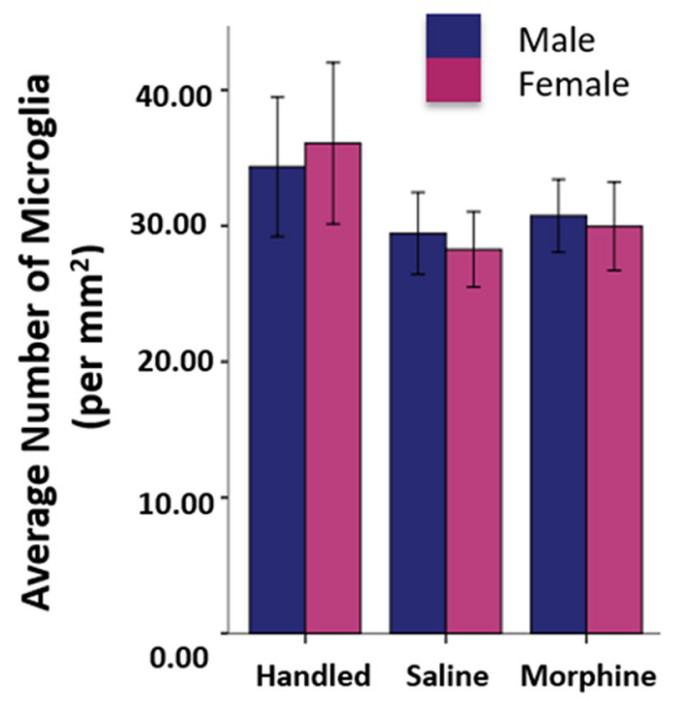

b

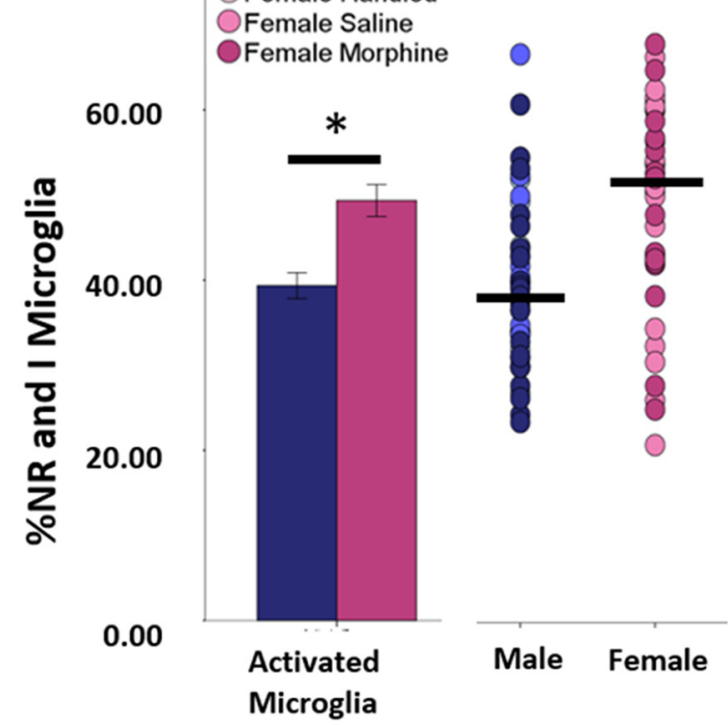

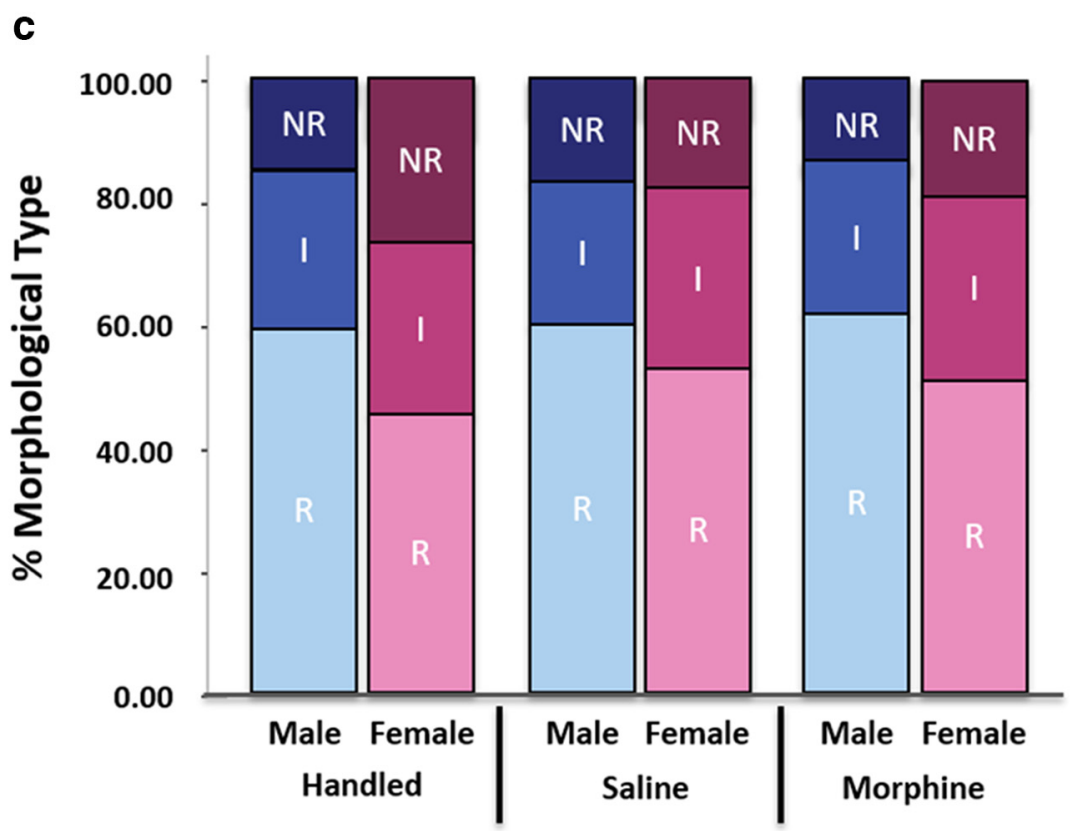

Figure 2. Sex, but not morphine treatment or time, affects microglia activation in the vIPAG. $\boldsymbol{a}$, No significant differences in microglia cell number were noted as a function of sex, time (collapsed), or treatment (handled: $n=5$ males, 6 females; saline: $n=15$ males, 17 females; morphine: $n=22$ males, 17 females). $\boldsymbol{b}$, Females had significantly more nonramified/amoeboid (NR) and intermediate (I) microglia than males regardless of treatment $\left(t_{(80)}=3.90, p<0.001\right)$. As shown in the scatterplot at right, the percentages of NR and I microglia were highly variable within each sex (line indicates median). c, Females had significantly more NR and I and fewer ramified (R) microglia in the vIPAG than males.

the PAG or if it extended to regions also implicated in pain (RVM) and/or regions with high levels of MOR (SN, SC) or a high density of microglia (MeA). For females, no significant correlation between morphine $\mathrm{ED}_{50}$ and the percentage of nonramified and intermediate microglia was observed in $\operatorname{RVM}(r=0.21, p=0.32), \mathrm{MeA}(r=0.48, p=0.12), \mathrm{SC}(r=$ $-0.05, p=0.46)$, or SN $(r=0.09, p=0.44)$. Similarly, in males, no significant correlations were observed in the RVM $(r=-0.13, p=0.35), \mathrm{MeA}(r=0.23, p=0.24)$, or SN $(r=$ $0.32, p=0.20)$. However, significant correlations between morphine $\mathrm{ED}_{50}$ and percentage of nonramified and interme- diate microglia were noted in SC of male rats $(r=0.53, p=$ 0.05 ; Fig. $3 c-g$ ).

Similar to what was observed for the PAG, no significant differences were observed in the total number of microglia in any of the brain regions examined $\left(F_{(3,28)}=0.152, p=0.93\right.$; data not shown), indicating that the difference in the number of activated cells between males and females is not due to increased proliferation or migration of activated microglia. Rather, these data indicate that morphine $\mathrm{ED}_{50}$ positively correlates with the overall percentage of nonramified and intermediate microglia, states typical of activation, in the PAG in 
a

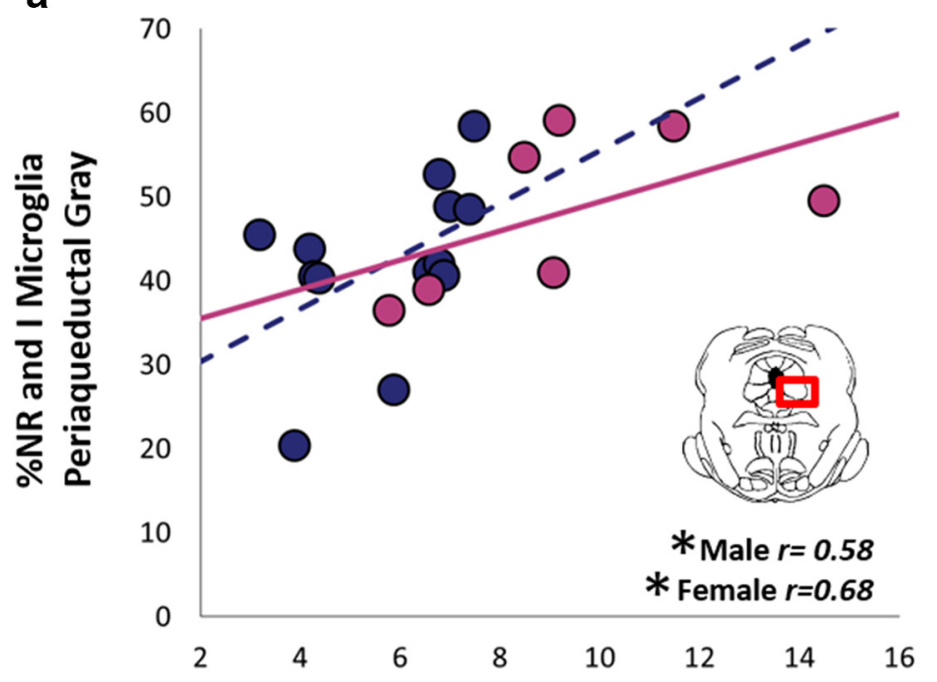

b

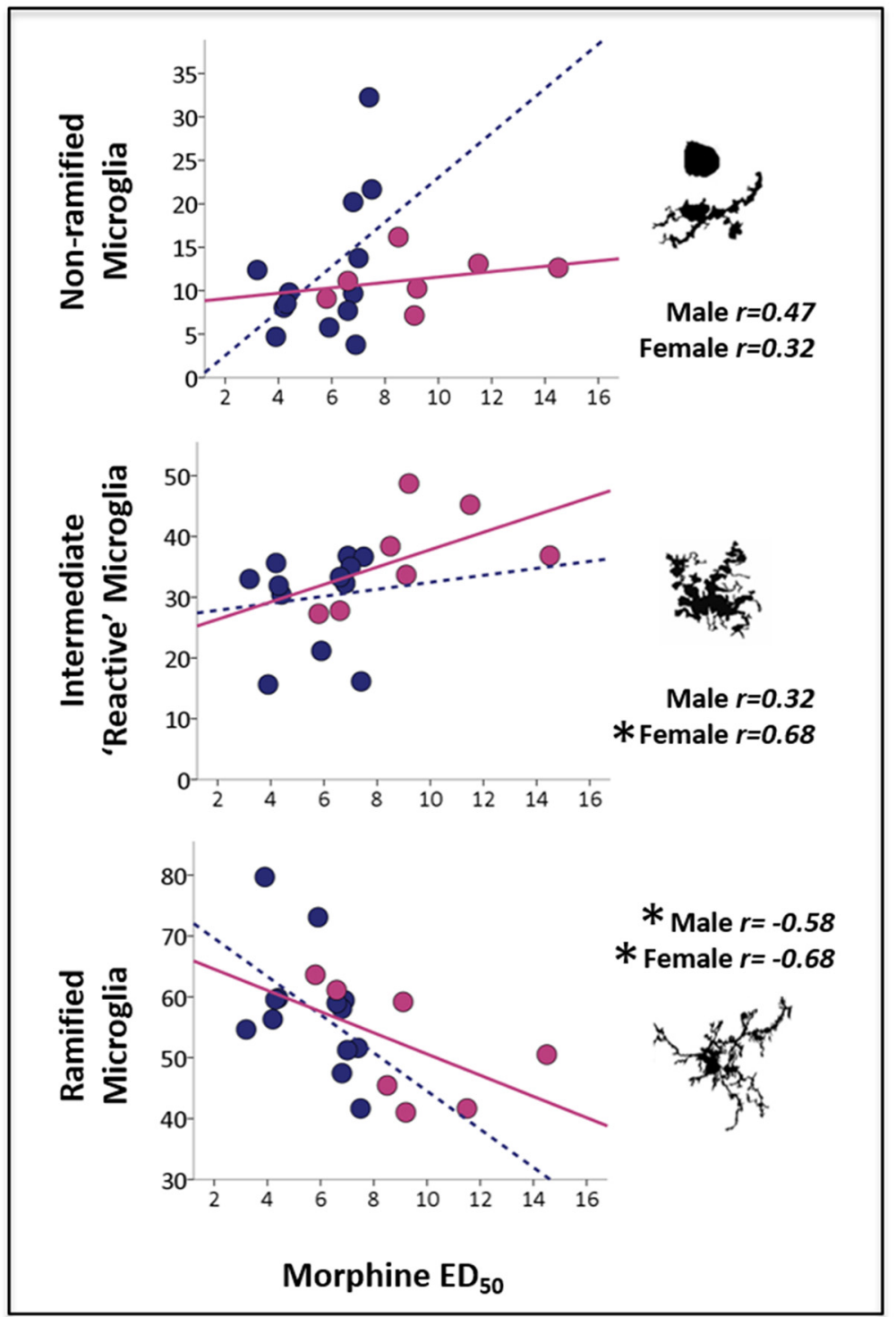

C

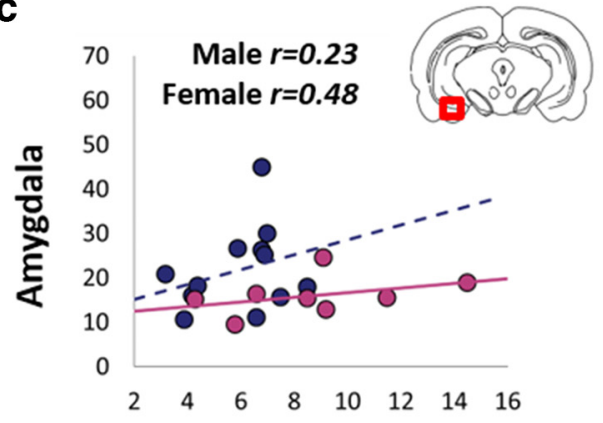

d

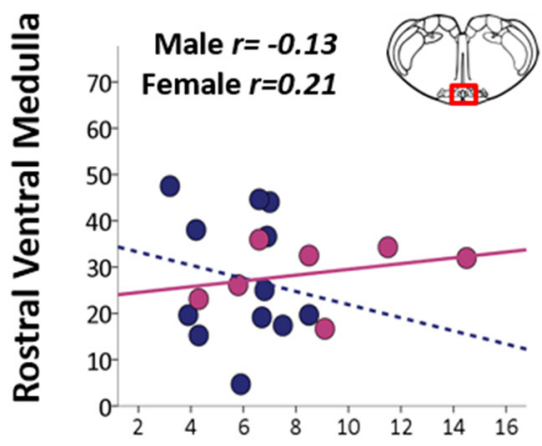

e

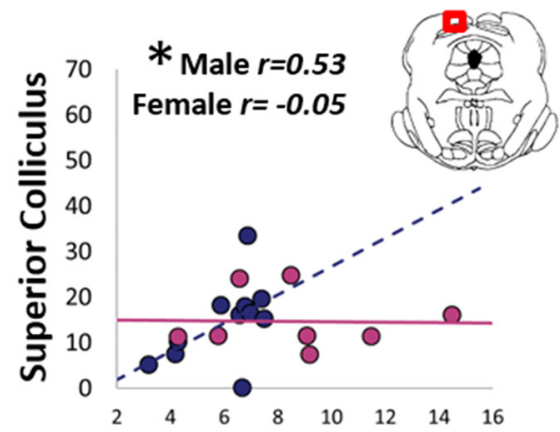

f

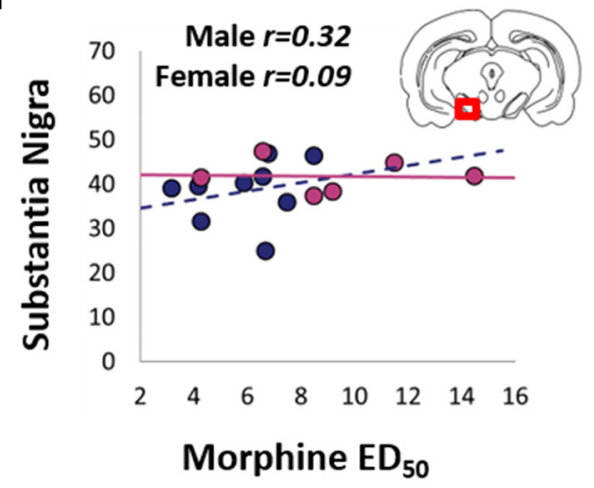

Figure 3. Percentage of activated microglia correlates with morphine effective dose. Bivariate correlations of morphine $\mathrm{ED}_{50}$ for the percentage of total nonramified and intermediate microglia $(\boldsymbol{a})$ and by morphological subtype within the PAG $(\boldsymbol{b})$ are shown. Degree of relatedness for morphine $\mathrm{ED}_{50}$ and microglia morphology are also shown for the MeA (c), rostral ventral medulla (d), SC $(\boldsymbol{e})$, and $\mathrm{SN}(\boldsymbol{f}) . n=15$ males, 8 females. 
males and females, with sex-specific differences in correlations noted for the SC.

\section{Experiment 3a: immune challenge activates vlPAG microglia to a greater extent in females than in males}

The results from the above experiment show that, although there were significantly more microglia with a nonramified or intermediate morphology in females than males, these microglia were unaffected by morphine treatment. Therefore, we next tested whether administration of LPS, a TLR4 agonist, activated vlPAG microglia in a sex-dependent manner. Peripheral administration of LPS induced a significant increase in the percentage of nonramified and intermediate microglia in the vlPAG of females (19\%), but not males (12\%; Fig. 4a); significant main effect of sex $\left(F_{(1,22)}=18.26, p<0.001\right)$ and treatment $\left(F_{(1,22)}=11.84, p<\right.$ $0.001)$. Similar to what was noted in Experiment 1, females had more nonramified and intermediate microglia in the PAG at baseline $(p=0.03)$.

Analysis of microglia by morphological subtype showed a significant main effect of both sex $\left(F_{(2,44)}=13.14, p=0.001\right)$ and treatment $\left(F_{(2,44)}=6.44, p=0.001\right)$ on microglia morphology and no interaction $\left(F_{(2,44)}=0.55, p=0.58\right)$. Specifically, salinetreated females had significantly more intermediate $(t=2.43$, $p=0.05)$ and significantly fewer ramified $(t=2.83, p=0.03)$ microglia than saline males. Similarly, LPS-treated females had significantly more intermediate $(t=2.95, p=0.01)$ and significantly fewer ramified $(t=3.10, p=0.01)$ microglia than LPS males (Fig. $4 b$ ), suggesting a more "activated" morphological state in females. The observed sex difference in microglia morphology in the PAG was not accompanied by differences in sickness behaviors because no sex differences in core body temperature were observed in animals treated with $\operatorname{LPS}\left(F_{(1,13)}=\right.$ $2.22, p=0.16$; Fig. $4 d$ ). These data suggest that, in females, PAG microglia may be more responsive to TLR4 activation (i.e., lower threshold) than their male counterpart.

No significant main effects of sex on total number of nonramified and intermediate microglia were observed in any other brain region examined (Fig. 4e). In contrast to what was noted with morphine, the main effects of LPS treatment were observed in several brain regions, including the SC $\left(F_{(1,20)}=10.862, p<\right.$ $0.001)$ in males $(p=0.01)$, but not females $(p=0.08)$, and the $\operatorname{RVM}\left(F_{(1,15)}=5.76, p=0.03\right)$ in males $(p=0.03)$, but not females $(p=0.32)$. No significant main effects of LPS treatment were observed in the MeA or SN and no interaction effects were observed in any brain region tested. Finally, no significant differences were observed in the total number of microglia in any brain regions examined (data not shown).

\section{Experiment $3 \mathrm{~b}$ : immune challenge induces greater cytokine expression in the vlPAG of females}

To determine whether the observed sex differences in PAG microglia morphology was accompanied by sex-specific differences in proinflammatory cytokine transcription, $\mathrm{qPCR}$ was used to quantify PAG mRNA levels of proinflammatory TNF, IL-1 $\beta$, IL-6, and anti-inflammatory IL-10 (Fig. 5). LPS induced a significant increase in vlPAG TNF transcription in both males $(p<$ $0.001)$ and females $(p<0.001)$ compared with saline controls $\left(F_{(1,42)}=50.72, p<0.001\right)$. LPS treatment also induced in a significant increase in IL- $1 \beta$ transcription in females $(p<0.001)$ and males $(p<0.001)$; a significant main effect of treatment $\left(F_{(1,38)}=47.08, p=0.00\right)$. Notably, IL- $1 \beta$ levels were significantly higher in LPS-treated females than males $(p=0.03)$. LPS did not change IL-6 significantly in either $\operatorname{sex}\left(F_{(1,34)}=0.19, p=\right.$
0.67). PAG transcription of the anti-inflammatory cytokine IL-10 was significantly higher in males than in females $\left(F_{(1,44)}=\right.$ $14.99, p<0.001)$. LPS induced a significant decrease in IL-10 mRNA in females $(t=3.33, p<0.001)$, but not males $(t=-0.19$, $p=0.86$; Fig. 5e). Together, these data demonstrate that PAG TLR4 activation induces an exaggerated proinflammatory response and a reduced anti-inflammatory response in females compared with males. Furthermore, these data support our immunohistochemical studies demonstrating that changes in microglial morphology are accompanied by measurable changes in proinflammatory cytokine mRNA.

We also examined LPS-induced changes in PAG TLR4 transcription. LPS administration increased TLR4 transcription by $67 \%$ in females and 39\% in males; however, these differences were not statistically significant (treatment, $F_{(1,40)}=2.37, p=$ 0.13 ; sex, $\left.F_{(1,40)}=2.37, p=0.13\right)$.

\section{Experiment 4: manipulation of PAG TLR4 signaling has sex-dependent effects on morphine $\mathrm{ED}_{50}$ values}

Our previous studies established a direct link between microglia activation and morphine efficacy, such that site-specific administration of the TLR4 agonist LPS resulted in a significant reduction in morphine efficacy (as indicated by a rightward shift in the morphine dose-response curve; Eidson and Murphy, 2013a). Given the results of the present experiments demonstrating that females show more nonramified and intermediate morphologies than males, we next examined whether this sex difference in microglia morphology would result in a sexually dimorphic shift in morphine $\mathrm{ED}_{50}$. In particular, we tested whether activation of vlPAG TLR4 via site-specific administration of the endotoxin LPS would result in a larger rightward shift in the morphine dose-response curve in females compared with males. We further examined whether blockade of TLR4 signaling with $(+)$ naloxone would result in a greater leftward shift of the morphine dose-response curve in females, which is indicative of potentiation of morphine antinociception in females.

Intra-PAG administration of LPS resulted in a significant decrease in morphine antinociception in both males and females, as indicated by a significant rightward shift in the morphine $\mathrm{ED}_{50}$ dose-response curve $\left(F_{(5,30)}=18.01, p<0.0001\right.$; Fig. $\left.6 a\right)$. LPS increased male $\mathrm{ED}_{50}$ values from 3.04 to $10.69 \mathrm{mg} / \mathrm{kg}$, a 3.5 -fold difference, $p<0.001$; female $\mathrm{ED}_{50}$ values increased from 7.9 to $20.61 \mathrm{mg} / \mathrm{kg}$, a 2.6 -fold difference, $p<0.05 . \mathrm{ED}_{50}$ values were approximately 2 -fold higher in LPS + Morphine females than males (20.61 in females vs $10.69 \mathrm{mg} / \mathrm{kg}$ in males; $p>0.05$ ). Remarkably, after LPS priming, $6 / 8$ females continued to respond at baseline levels following morphine administration at $10 \mathrm{mg} / \mathrm{kg} ; 2$ of those 6 females responded near baseline after the $18 \mathrm{mg} / \mathrm{kg}$ dose. Indeed, females in the LPS + Morphine-treated groups were not significantly different from saline control females that received no morphine (Saline + Saline females; $p>0.05$ ), indicating that LPS pretreatment completely abolished the antinociceptive effects of morphine in a subset of females. No differences in response latencies were observed between LPS + Morphine males and Saline + Morphine females $(p>0.05)$, indicating that LPS activation of microglia reduced males to "female-typical" levels of analgesia.

No sex differences were observed between Saline + Salinetreated males and females $(p>0.05)$, and no significant differences were observed between LPS + Saline and Saline + Saline males $(p>0.05)$ or females $(p>0.05)$, indicating that LPS administration alone had no effect on basal PWL, consistent with what we have observed previously (Eidson and Murphy, 2013a). Together, these results indicate that microglia activation with 

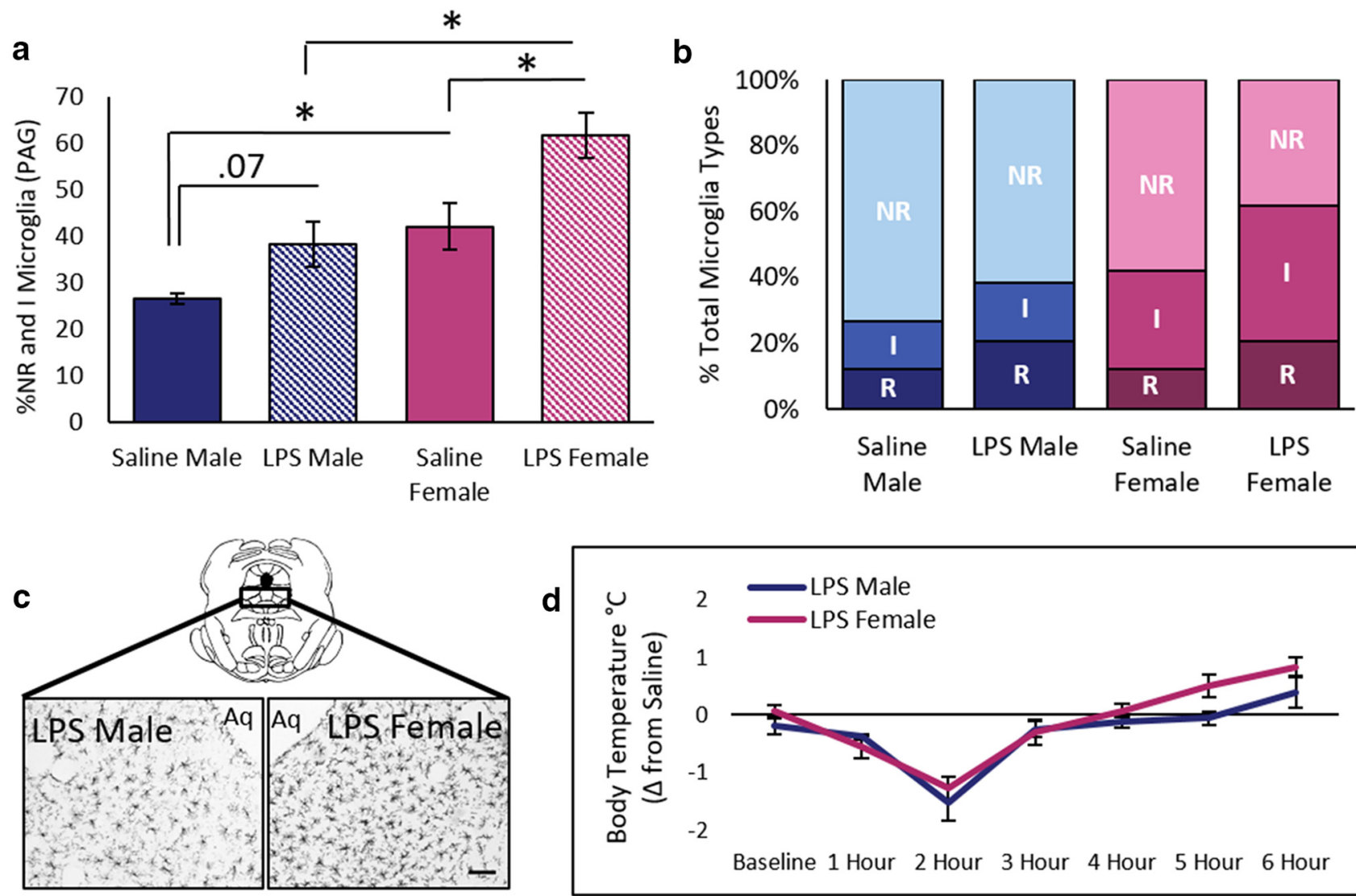

e
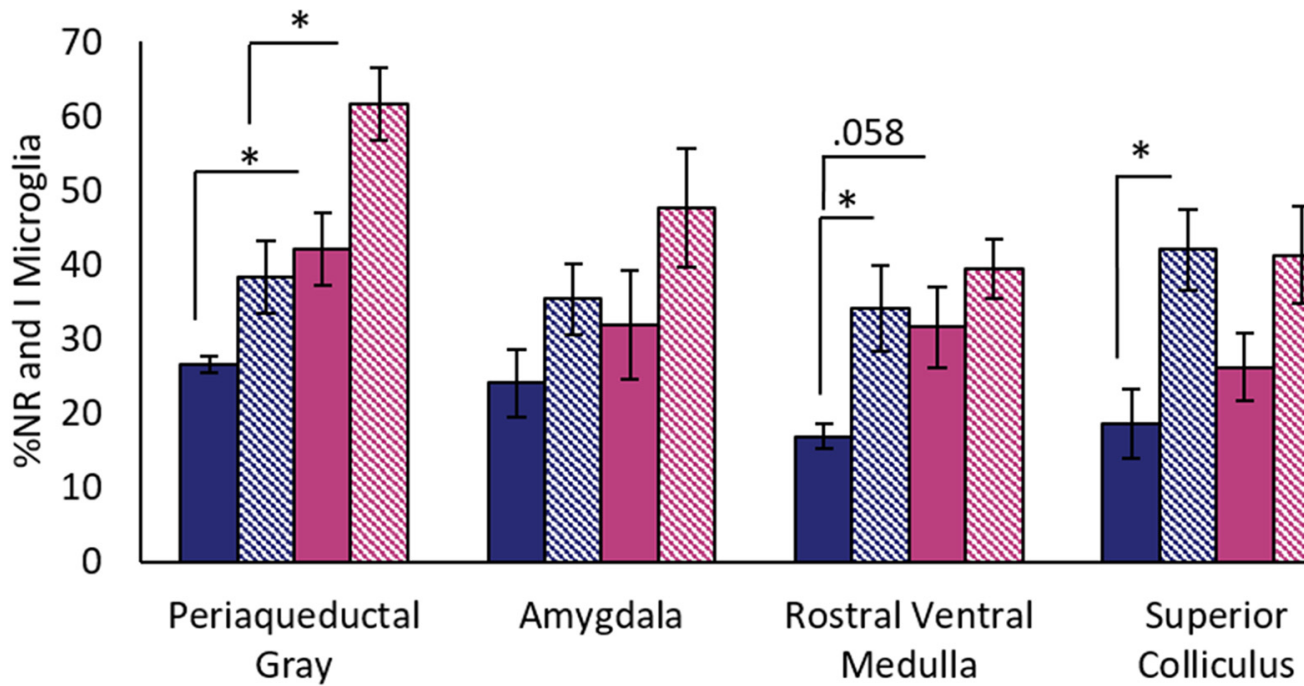

$\square$ Saline Male

ه LPS Male

$\square$ Saline Female

$\mathbb{Q}$ LPS Female

Figure 4. Treatment with TLR4 agonist LPS increases microglia activation in females. $\boldsymbol{a}$, LPS induces greater proportions of nonramified/amoeboid (NR) and intermediate (I) microglia in the PAG of females than males. $\boldsymbol{b}$, LPS-treated females had a higher percentage of I microglia in the vIPAG than saline-treated females and show decreased percentage of ramified (R) microglia compared with all other groups. $c$, Representative images of microglia in the vIPAG of an LPS-treated male and female. Note that females have a greater density of nonramified and intermediate microglia than males. Scale bar, $5 \mu \mathrm{m}$. $\boldsymbol{d}$, No sex differences in febrile response were noted after LPS administration. $\boldsymbol{e}$, Percentage of nonramified and intermediate microglia for males and females after saline or LPS administration. LPS-induced increases in activated microglia were region and sex dependent. Endotoxin LPS, $n=7$ males, 6 females; saline, $n=7$ males, 6 females.

LPS significantly decreases or completely abolishes (in 33\% of females) the antinociceptive effects of morphine.

We next determined whether blocking microglia activation with the TLR4-specific antagonist $(+)$-naloxone potentiated morphine analgesia in a sex-dependent manner. In animals treated with morphine, intra-PAG administration of $(+)$ naloxone significantly increased antinociception in females, but not males, as indicated by a leftward shift in the morphine doseresponse curve $\left(F_{(3,18)}=13.67, p<0.0001\right.$; Fig. $\left.6 b\right)$. Specifically, $\mathrm{ED}_{50}$ values for females treated with $(+)$-naloxone decreased 

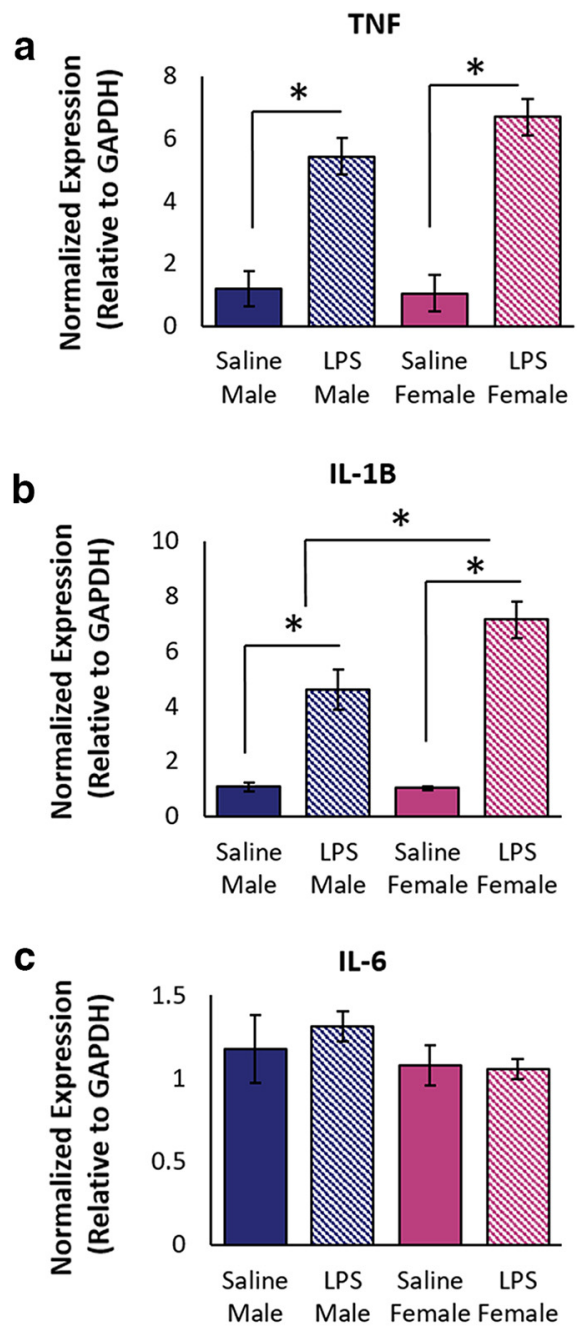

d

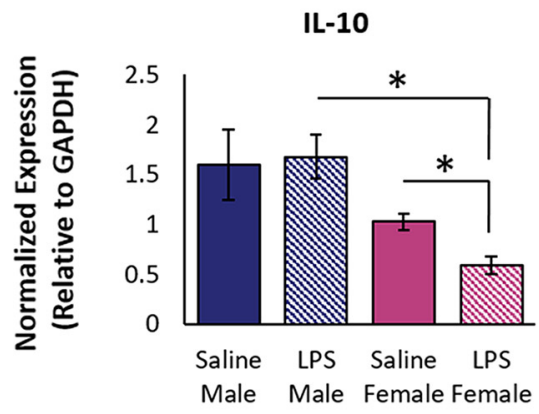

e

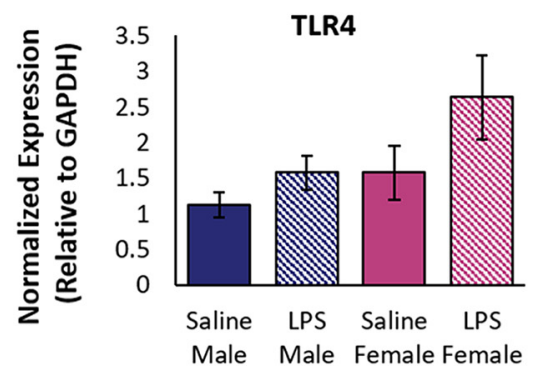

Figure 5. LPS-induced changes in cytokine and TLR4 transcription in the VIPAG of males and females. Peripheral administration of LPS increased the transcription of TNF $(\boldsymbol{a})$ and IL-1 $\beta(\boldsymbol{b})$ in the vIPAG. $\boldsymbol{c}$, No change in IL-6 was noted. $\boldsymbol{d}$, Transcription of the anti-inflammatory cytokine IL-10 significantly decreased in females after LPS. $\boldsymbol{e}$, No differences in TLR4 transcription were noted for sex or treatment. Endotoxin LPS, $n=5$ males, 5 females; saline, $n=3$ males, 3 females. from 7.9 to $3.16 \mathrm{mg} / \mathrm{kg}$ ( $p<0.001)$, a 2.5 -fold reduction in $\mathrm{ED}_{50}$. Importantly, $\mathrm{ED}_{50}$ values for $(+)$-Naloxone + Morphine-treated females were not significantly different from Saline + Morphinetreated males $(p>0.05)$, indicating that blocking microglia activation within the vlPAG completely abolishes sex differences in morphine analgesia. A moderate, but significant, increase in morphine $\mathrm{ED}_{50}$ was observed in males receiving $(+)$-Naloxone + Morphine compared with Saline + Morphine males $\left(\mathrm{ED}_{50}\right.$ increased from $3.04 \mathrm{mg} / \mathrm{kg}$ vs $5.25 \mathrm{mg} / \mathrm{kg} ; p<0.05)$.

No sex differences between Saline + Saline-treated males and females $(p>0.05)$ were observed. In addition, we observed no significant differences between $(+)$-Naloxone + Saline and Saline + Saline controls in males $(p>0.05)$ or females $(p>0.05)$, indicating that $(+)$-naloxone administration had no effect on basal nociceptive thresholds. The effects of $(+)$-naloxone on morphine analgesia are site specific; male and female animals receiving (+)-naloxone outside of the PAG showed significantly lower morphine antinociception relative to animals that received $(+)$-naloxone within the PAG $\left(F_{(3,18)}=15.17\right.$, $p<0.001$; data not shown). Together, these data indicate inhibition of vlPAG microglia activity with the TLR4-specific antagonist $(+)$-naloxone is sufficient to reverse sex differences in morphine analgesia.

\section{Discussion}

Here, we test the hypothesis that sex differences in vlPAG microglia contribute to the sexually dimorphic effects of morphine. We report that, although no sex differences in overall number or density of microglia were noted for the vlPAG at baseline, the percentage of "nonramified" and "intermediate" versus "ramified" microglia were significantly higher in females than males, suggesting that females have a more "activated" microglial state within the vlPAG. Consistent with our previous studies, morphine $\mathrm{ED}_{50}$ values were significantly higher in females (Loyd et al., 2008a; Loyd et al., 2008b) and a significant relationship was observed between morphine potency and percentage of reactive "intermediate" microglia in females, but not males. Although acute morphine treatment did not change microglia morphology in either sex, administration of the glial TLR4 agonist LPS increased the percentage of nonramified and intermediate microglia in the vlPAG of females to a greater degree than males, an effect that was independent of febrile response. LPS-induced increases in microglia activation in females were accompanied by significantly increased proinflammatory IL- $1 \beta$ transcription and decreased anti-inflammatory IL-10 transcription. We further show that priming microglia with LPS significantly attenuates morphine analgesia in both sexes and completely abolishes the antinociceptive response to morphine in a subset of females. Similarly, inhibition of vlPAG microglia with the TLR4 antagonist $(+)$-naloxone significantly potentiates morphine analgesia in females, but not males, abolishing the sex difference in opiate response. Together, these data indicate that vlPAG microglia are innately different in males and females in terms of their morphological state (both basal and after immune activation with LPS) and implicate TLR4 in the attenuated response to morphine observed in females.

\section{Sex differences in morphine analgesia and TLR4}

Preclinical studies using orofacial, somatosensory, or visceral pain assays typically report that morphine produces a significantly greater degree of analgesia in males versus females (Craft, 2003; Craft et al., 2004; Ji et al., 2006; Wang et al., 2006; Loyd et al., 2008b). Consistent with the present results, these studies also report morphine $\mathrm{ED}_{50}$ 
a

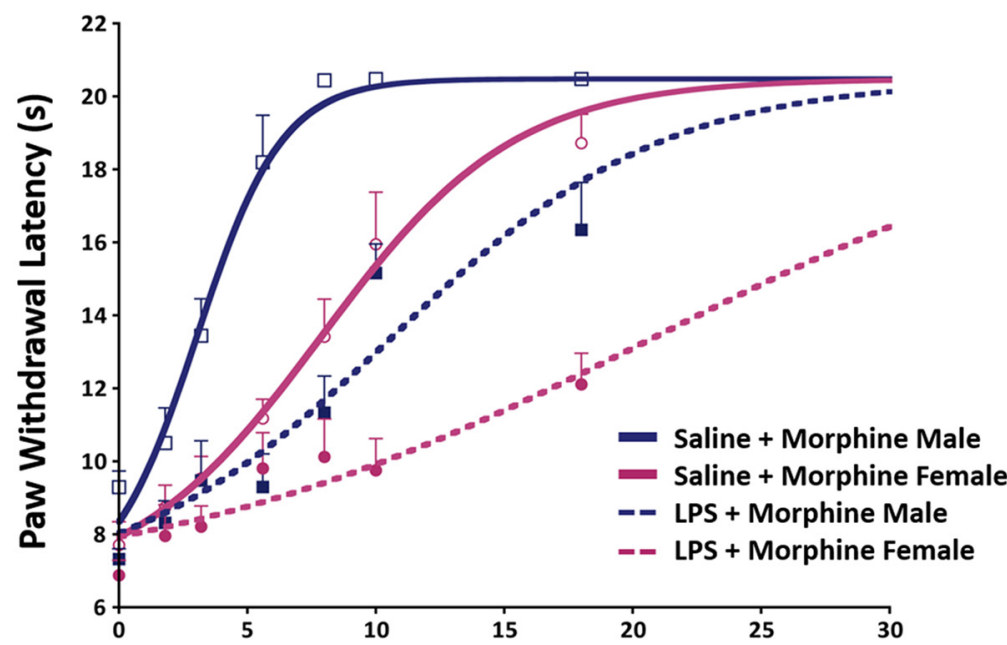

b

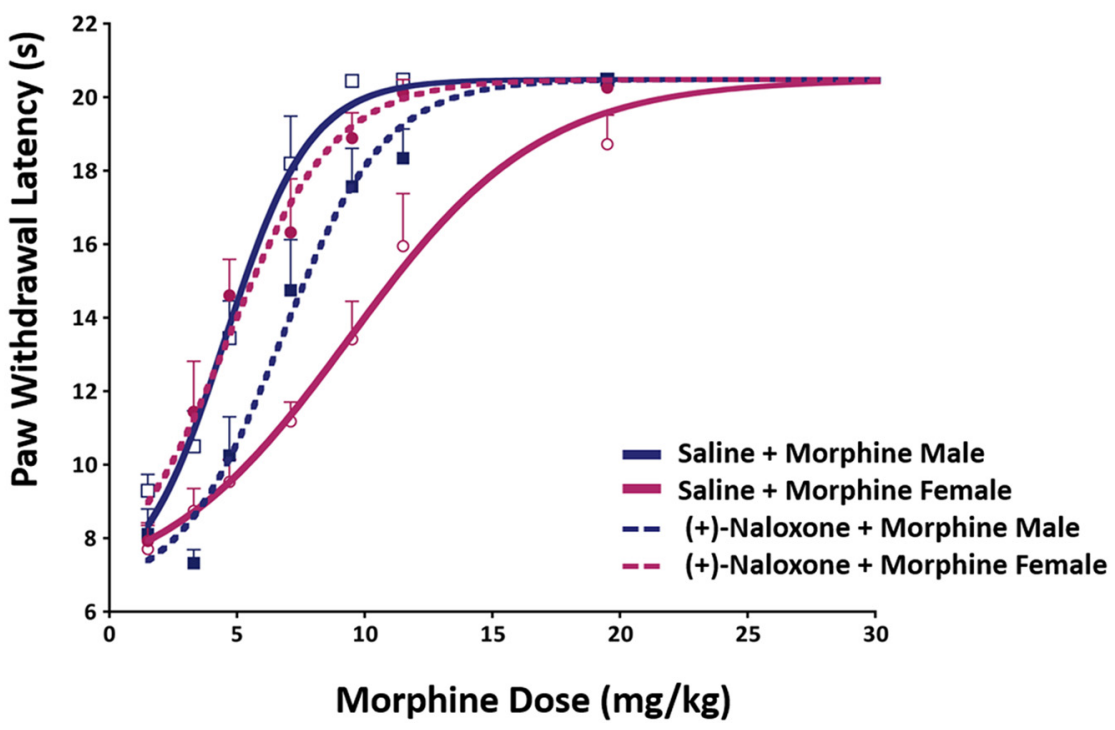

Figure 6. Pharmacological blockade or activation of vIPAG microglia has a sex-dependent impact on morphine antinociception. $\boldsymbol{a}$, LPS-induced activation of vIPAG microglia significantly attenuates the antinociceptive effects of morphine in both males and females, as indicated by a significant rightward shift in the morphine dose-response curve. Saline + Saline $(n=5$ males, 5 females), LPS + Saline ( $n=5$ males, 5 females), Saline + Morphine ( $n=8$ males, 11 females), and LPS + Morphine $(n=7$ males, 8 females). $\boldsymbol{b}$, In contrast, inhibition of TLR4 via intra-vIPAG (+)-naloxone results in a significant leftward shift in morphine dose-response curves in females such that $(+)$-Naloxone + Morphine-treated females were not significantly different from Saline + Morphine-treated males. Naloxone + Saline $(n=5$ males, 5 females); Naloxone + Morphine ( $n=7$ males, 9 females).

values that are 2 -fold higher in females than in males. The present studies demonstrate that sex differences in PAG microglia, and in particular TLR4 signaling, contribute to the dimorphic response to morphine. TLR4 signaling has been shown previously to modulate morphine action in males (Tanga et al., 2005; Hutchinson et al., 2007; Hutchinson et al., 2008a; Hutchinson et al., 2008b) such that TLR4 activation with LPS reduces morphine efficacy (Johnston and Westbrook, 2005). The present studies confirm these previous findings in males and further demonstrate that initiation of TLR4 signaling significantly, and almost completely, attenuates morphine analgesia in females. In addition, blockade of vlPAG TLR4 increases the analgesic efficacy of morphine in females (2.5-fold reduction in morphine $\mathrm{ED}_{50}$ ), reversing the observed sex difference in morphine response.

Several factors have been shown to contribute to the sexually dimorphic response to morphine. Interestingly, these factors are also heavily impacted by microglia. For example, blockade of NMDA signaling inhibits microglia activation (Thomas and Kuhn, 2005; Murugan et al., 2011) and enhances the antinociceptive effects of morphine to a greater degree in males than females (Picker et al., 2011). Sex differences in MOR expression and signaling in the PAG (Bernal et al., 2007; Loyd et al., 2008b), as well as spinal MOR:KOR dimerization (Chakrabarti et al., 2010), have also been shown to contribute to the dimorphic effects of morphine. MOR expression is rapidly upregulated after peripheral inflammation and cytokine release in male rats (Ji et al., 1995; Mousa, 2003; Puehler et al., 2004), likely a homeostatic response that counteracts the excitatory effects of glial activation and thereby increases opioid efficacy. Interestingly, no change in MOR expression is noted in female rats after peripheral inflammation (Zhang et al., 2014), which may also contribute to the reduced antinociceptive effects of morphine observed in persistent pain assays (Cook and Nickerson, 2005; Loyd and Murphy, 2006; Wang et al., 2006; Murphy et al., 2009). We speculate that NMDAR and MOR activity represent downstream or parallel targets of microglia activation and may explain the existence of multiple mechanisms underlying the sexually dimorphic response to morphine.

Sex-specific differences in TLR4 modulation of pain have been reported previously (Sorge et al., 2011; Sorge et al., 2015). For example, in mice, inhibition or transient depletion of spinal microglia reverses mechanical allodynia induced by spared nerve injury in males, but not females, suggesting that spinally mediated chronic pain in females is maintained in a non-TLR-dependent manner (e.g., an adaptive immunedependent response; Sorge et al., 2015). In the present study, chronic pain was not induced; rather, LPS was administered to activate microglia in a TLR4-dependent manner. Sex-specific effects of TLR4 activity exemplify the need to consider both sexes when studying immune responses and the development of drugs affecting immune signaling. Because TLR4 has also been shown to mediate the rewarding effects of morphine (Hutchinson et al., 2012) and the development of tolerance to morphine (Eidson and Murphy, 2013b; Eidson et al., 2017), sex differences in TLR4 signaling may have broad implications for the treatment of chronic pain in men and women.

\section{Sex differences in innate immune function}

In the present study, we show that female rats have significantly more "activated" microglia in the PAG than males at baseline, a difference that is potentiated after systemic LPS treatment. This finding suggests that females have a lower threshold for activation and/or launch a more robust proinflammatory response com- 
pared with males. Indeed, females of many species launch a more robust immune response than males (Gaillard and Spinedi, 1998; Klein, 2000; Schwarz and Bilbo, 2012). For example, in the peripheral immune system, female mice have higher titers of immunoglobulins (Klein, 2000) and splenocyte blastogenic responses to T- and B-cell mitogens than males (Schneider et al., 2006). Centrally, females often present with greater levels of proinflammatory markers after immune challenge (Tonelli et al., 2008; Bollinger et al., 2016). Interestingly, despite increases in PAG microglia activation and IL- $1 \beta$ release in response to LPS immune challenge in females, we observed no sex differences in LPS-induced febrile response. However, IL-6, which correlates most closely with changes in body temperature (LeMay et al., 1990; Roth et al., 1993; Roth and De Souza, 2001), was not different in males and females and may account for the lack of observed sex difference in fever response.

The present experiments used normally cycling female rats. Estrous cycle was monitored, but not controlled or manipulated, to demonstrate physiologically relevant changes in microglia activation as a function of estrous cycle. No significant effect of estrous cycle was observed in any of the present experiments. Immunomodulatory effects of sex hormones, specifically estradiol, have been shown to alter cytokine release and microglial activation in a concentration-, age-, and duration-dependent manner. For example, uterine TNF, IL-1 $\beta$, and IL- 6 levels increase during proestrous and estrous in rats (De et al., 1992), when estradiol is high. This coincides with our previous data demonstrating that morphine is least effective in reducing nociception during proestrous (Loyd et al., 2008b). Historically, estradiol is thought to be neuroprotective, but these effects may be biphasic (Whitacre et al., 1999) such that high levels of estradiol decrease inflammatory markers and attenuate the inflammatory response to LPS (Dimayuga et al., 2005), whereas low doses comparable to normal circulating levels increase concentrations of proinflammatory cytokines (Correale et al., 1998). Furthermore, chronic but not acute estradiol administration increases proinflammatory responses in peripheral immune cells of females compared with males (Calippe et al., 2008; Calippe et al., 2010) and potentiates LPS-evoked TLR4 immune responses in vitro (Loram et al., 2012). Consistent with clinical research demonstrating that women have a much higher incidence rate of autoimmune disorders and chronic inflammatory conditions such as migraine (Buse et al., 2013), osteoarthritis, and rheumatoid arthritis (Whitacre, 2001) compared with men, these results suggest that women may have increased susceptibility to immune challenge and are at a greater risk for developing inflammatory pathologies than men.

\section{Summary}

These studies are the first to implicate vlPAG microglial TLR4 in sex differences in morphine analgesia and suggest that increased activation of vlPAG microglia contribute to the attenuated response to morphine observed in females. Importantly, these experiments establish that inhibition of vlPAG TLR4 in females reverses the observed sex differences in morphine analgesia. Together, these data suggest novel methods to improve current morphine-based pain management via inhibition of TLR4 and illustrate the necessity for sex-specific research and individualized treatment of pain in men and women.

\section{References}

Bernal SA, Morgan MM, Craft RM (2007) PAG mu opioid receptor activation underlies sex differences in morphine antinociception. Behav Brain Res 177:126-133. CrossRef Medline
Bland ST, Beckley JT, Young S, Tsang V, Watkins LR, Maier SF, Bilbo SD (2010) Enduring consequences of early-life infection on glial and neural cell genesis within cognitive regions of the brain. Brain Behav Immun 24:329-338. CrossRef Medline

Bobeck EN, McNeal AL, Morgan MM (2009) Drug dependent sex-differences in periaqueducatal gray mediated antinociception in the rat. Pain 147:210-216. CrossRef Medline

Bollinger JL, Bergeon Burns CM, Wellman CL (2016) Differential effects of stress on microglial cell activation in male and female medial prefrontal cortex. Brain Behav Immun 52:88-97. CrossRef Medline

Bonizzi G, Karin M (2004) The two NF-kappaB activation pathways and their role in innate and adaptive immunity. Trends Immunol 25:280288. CrossRef Medline

Buse DC, Loder EW, Gorman JA, Stewart WF, Reed ML, Fanning KM, Serrano D, Lipton RB (2013) Sex differences in the prevalence, symptoms, and associated features of migraine, probable migraine and other severe headache: results of the American Migraine Prevalence and Prevention (AMPP) Study. Headache 53:1278-1299. CrossRef Medline

Buttini M, Boddeke H (1995) Peripheral lipopolysaccharide stimulation induces interleukin-1 beta messenger RNA in rat brain microglial cells. Neuroscience 65:523-530. CrossRef Medline

Buttini M, Limonta S, Boddeke HW (1996) Peripheral administration of lipopolysaccharide induces activation of microglial cells in rat brain. Neurochem Int 29:25-35. CrossRef Medline

Calippe B, Douin-Echinard V, Laffargue M, Laurell H, Rana-Poussine V, Pipy B, Guéry JC, Bayard F, Arnal JF, Gourdy P (2008) Chronic Estradiol Administration In Vivo Promotes the Proinflammatory Response of Macrophages to TLR4 Activation: Involvement of the Phosphatidylinositol 3-Kinase Pathway. J Immunol 180:7980-7988. CrossRef Medline

Calippe B, Douin-Echinard V, Delpy L, Laffargue M, Lélu K, Krust A, Pipy B, Bayard F, Arnal JF, Guéry JC, Gourdy P (2010) 17Beta-estradiol promotes TLR4-triggered proinflammatory mediator production through direct estrogen receptor alpha signaling in macrophages in vivo. J Immunol 185:1169-1176. CrossRef Medline

Castaño A, Herrera AJ, Cano J, Machado A (2002) The degenerative effect of a single intranigral injection of LPS on the dopaminergic system is prevented by dexamethasone, and not mimicked by rh-TNF-alpha, IL-1beta and IFN-gamma. J Neurochem 81:150-157. CrossRef Medline

Chakrabarti S, Liu NJ, Gintzler AR (2010) Formation of mu-/kappa-opioid receptor heterodimer is sex-dependent and mediates female-specific opioid analgesia. Proc Natl Acad Sci U S A 107:20115-20119. CrossRef

Colton C, Wilcock DM (2010) Assessing activation states in microglia. CNS Neurol Disord Drug Targets 9:174-191. CrossRef Medline

Cook CD, Nickerson MD (2005) Nociceptive sensitivity and opioid antinociception and antihyperalgesia in Freund's adjuvant-induced arthritic male and female rats. J Pharmacol Exp Ther 313:449-459. Medline

Correale J, Arias M, Gilmore W (1998) Steroid hormone regulation of cytokine secretion by proteolipid protein-specific $\mathrm{CD} 4+\mathrm{T}$ cell clones isolated from multiple sclerosis patients and normal control subjects. J Immunol 161:3365-3374. Medline

Craft RM (2003) Sex differences in opioid analgesia: "from mouse to man". Clin J Pain 19:175-186. CrossRef Medline

Craft RM, Mogil JS, Aloisi AM (2004) Sex differences in pain and analgesia: the role of gonadal hormones. Eur J Pain 8:397-411. CrossRef Medline

Craft RM, Ulibarri C, Leitl MD, Sumner JE (2008) Dose- and timedependent estradiol modulation of morphine antinociception in adult female rats. Eur J Pain 12:472-479. CrossRef Medline

Czerniawski J, Guzowski JF (2014) Acute neuroinflammation impairs context discrimination memory and disrupts pattern separation processes in hippocampus. J Neurosci 34:12470-12480. CrossRef Medline

Dawson-Basoa MB, Gintzler AR (1993) 17-Beta-estradiol and progesterone modulate an intrinsic opioid analgesic system. Brain Res 601:241-245. CrossRef Medline

De M, Sanford TR, Wood GW (1992) Interleukin-1, interleukin-6, and tumor necrosis factor alpha are produced in the mouse uterus during the estrous cycle and are induced by estrogen and progesterone. Dev Biol 151:297-305. CrossRef Medline

Dimayuga FO, Reed JL, Carnero GA, Wang C, Dimayuga ER, Dimayuga VM, Perger A, Wilson ME, Keller JN, Bruce-Keller AJ (2005) Estrogen and brain inflammation: effects on microglial expression of MHC, costimulatory molecules and cytokines. J Neuroimmunol 161:123-136. CrossRef Medline 
Dowell D, Haegerich TM, Chou R (2016) CDC guideline for prescribing opioids for chronic pain-United States, 2016. JAMA 315:1624-1645. CrossRef Medline

Doyle SL, O'Neill LA (2006) Toll-like receptors: from the discovery of NFkappaB to new insights into transcriptional regulations in innate immunity. Biochem Pharmacol 72:1102-1113. CrossRef Medline

Eidson LN, Murphy AZ (2013a) Blockade of Toll-like receptor 4 attenuates morphine tolerance and facilitates the pain relieving properties of morphine. J Neurosci 33:15952-15963. CrossRef Medline

Eidson LN, Murphy AZ (2013b) Persistent peripheral inflammation attenuates morphine-induced periaqueductal gray glial cell activation and analgesic tolerance in the male rat. J Pain 14:393-404. CrossRef Medline

Eidson LN, Inoue K, Young LJ, Tansey MG, Murphy AZ (2017) Toll-like receptor 4 mediates morphine-induced neuroinflammation and tolerance via soluble tumor necrosis factor signaling. Neuropsychopharmacology 42:661-670. CrossRef Medline

Franchi S, Moretti S, Castelli M, Lattuada D, Scavullo C, Panerai AE, Sacerdote $\mathrm{P}$ (2012) Mu opioid receptor activation modulates Toll like receptor 4 in murine macrophages. Brain Behav Immun 26:480-488. CrossRef Medline

Frank MG, Wieseler-Frank JL, Watkins LR, Maier SF (2006) Rapid isolation of highly enriched and quiescent microglia from adult rat hippocampus: immunophenotypic and functional characteristics. J Neurosci Methods 151:121-130. CrossRef Medline

Gaillard RC, Spinedi E (1998) Sex- and stress-steroids interactions and the immune system: evidence for a neuroendocrine-immunological sexual dimorphism. Domest Anim Endocrinol 15:345-352. CrossRef Medline

Hargreaves K, Dubner R, Brown F, Flores C, Joris J (1988) A new and sensitive method for measuring thermal nociception in cutaneous hyperalgesia. Pain 32:77-88. CrossRef Medline

Hernández-Romero MC, Argüelles S, Villarán RF, de Pablos RM, Delgado-Cortés MJ, Santiago M, Herrera AJ, Cano J, Machado A (2008) Simvastatin prevents the inflammatory process and the dopaminergic degeneration induced by the intranigral injection of lipopolysaccharide. J Neurochem 105:445-459. CrossRef Medline

Hutchinson MR, et al. (2010) Evidence that opioids may have toll-like receptor 4 and MD-2 effects. Brain Behav Immun 24:83-95. CrossRef Medline

Hutchinson MR, et al. (2012) Opioid activation of toll-like receptor 4 contributes to drug reinforcement. J Neurosci 32:11187-11200. CrossRef Medline

Hutchinson MR, Bland ST, Johnson KW, Rice KC, Maier SF, Watkins LR (2007) Opioid-induced glial activation: mechanisms of activation and implications for opioid analgesia, dependence, and reward. ScientificWorldJournal 7:98-111. Medline

Hutchinson MR, Zhang Y, Brown K, Coats BD, Shridhar M, Sholar PW, Patel SJ, Crysdale NY, Harrison JA, Maier SF, Rice KC, Watkins LR (2008a) Non-stereoselective reversal of neuropathic pain by naloxone and naltrexone: involvement of toll-like receptor 4 (TLR4). Eur J Neurosci 28: 20-29. CrossRef Medline

Hutchinson MR, Northcutt AL, Chao LW, Kearney JJ, Zhang Y, Berkelhammer DL, Loram LC, Rozeske RR, Bland ST, Maier SF, Gleeson TT, Watkins LR (2008b) Minocycline suppresses morphine-induced respiratory depression, suppresses morphine-induced reward, and enhances systemic morphine-induced analgesia. Brain Behav Immun 22:1248-1256. CrossRef Medline

Hutchinson MR, Coats BD, Lewis SS, Zhang Y, Sprunger DB, Rezvani N, Baker EM, Jekich BM, Wieseler JL, Somogyi AA, Martin D, Poole S, Judd CM, Maier SF, Watkins LR (2008c) Proinflammatory cytokines oppose opioid-induced acute and chronic analgesia. Brain Behav Immun 22: 1178-1189. CrossRef Medline

Ji RR, Zhang Q, Law PY, Low HH, Elde R, Hökfelt T (1995) Expression of mu-, delta-, and kappa-opioid receptor-like immunoreactivities in rat dorsal root ganglia after carrageenan-induced inflammation. J Neurosci 15:8156-8166. Medline

Ji Y, Murphy AZ, Traub RJ (2006) Sex differences in morphine-induced analgesia of visceral pain are supraspinally and peripherally mediated. Am J Physiol Regul Integr Comp Physiol 291:R307-R314. CrossRef

Johnston IN, Westbrook RF (2005) Inhibition of morphine analgesia by LPS: role of opioid and NMDA receptors and spinal glia. Behav Brain Res 156:75-83. CrossRef Medline

Jou I, Lee JH, Park SY, Yoon HJ, Joe EH, Park EJ (2006) Gangliosides trigger inflammatory responses via TLR4 in brain glia. Am J Pathol 168:16191630. CrossRef Medline

Karperien A, Ahammer H, Jelinek HF (2013) Quantitating the subtleties of microglial morphology with fractal analysis. Front Cell Neurosci 7:3. CrossRef Medline

Kettenmann H, Hanisch UK, Noda M, Verkhratsky A (2011) Physiology of microglia. Physiol Rev 91:461-553. CrossRef Medline

Klein SL (2000) The effects of hormones on sex differences in infection: from genes to behavior. Neurosci Biobehav Rev 24:627-638. CrossRef Medline

Krzanowska EK, Bodnar RJ (1999) Morphine antinociception elicited from the ventrolateral periaqueductal gray is sensitive to sex and gonadectomy differences in rats. Brain Res 821:224-230. CrossRef Medline

Laprairie JL, Murphy AZ (2009) Neonatal injury alters adult pain sensitivity by increasing opioid tone in the periaqueductal gray. Front Behav Neurosci 3:31. CrossRef Medline

Lehnardt S, Lachance C, Patrizi S, Lefebvre S, Follett PL, Jensen FE, Rosenberg PA, Volpe JJ, Vartanian T (2002) The toll-like receptor TLR4 is necessary for lipopolysaccharide-induced oligodendrocyte injury in the CNS. J Neurosci 22:2478-2486. Medline

Lehnardt S, Massillon L, Follett P, Jensen FE, Ratan R, Rosenberg PA, Volpe JJ, Vartanian T (2003) Activation of innate immunity in the CNS triggers neurodegeneration through a Toll-like receptor 4-dependent pathway. Proc Natl Acad Sci U S A 100:8514-8519. CrossRef Medline

LeMay LG, Vander AJ, Kluger MJ (1990) Role of interleukin 6 in fever in rats. Am J Physiol 258:R798-R803. Medline

Lenz KM, Nugent BM, Haliyur R, McCarthy MM (2013) Microglia are essential to masculinization of brain and behavior. J Neurosci 33:27612772. CrossRef Medline

Li Q (2012) Antagonists of toll like receptor 4 maybe a new strategy to counteract opioid-induced hyperalgesia and opioid tolerance. Med Hypotheses 79:754-756. CrossRef Medline

Loram LC, Sholar PW, Taylor FR, Wiesler JL, Babb JA, Strand KA, Berkelhammer D, Day HE, Maier SF, Watkins LR (2012) Sex and estradiol influence glial pro-inflammatory responses to lipopolysaccharide in rats. Psychoneuroendocrinology 37:1688-1699. CrossRef Medline

Loyd DR, Murphy AZ (2006) Sex differences in the anatomical and functional organization of the periaqueductal gray-rostral ventromedial medullary pathway in the rat: a potential circuit mediating the sexually dimorphic actions of morphine. J Comp Neurol 496:723-738. CrossRef Medline

Loyd DR, Morgan MM, Murphy AZ (2007) Morphine preferentially activates the periaqueductal gray-rostral ventromedial medullary pathway in the male rat: a potential mechanism for sex differences in antinociception. Neuroscience 147:456-468. CrossRef Medline

Loyd DR, Morgan MM, Murphy AZ (2008a) Sexually dimorphic activation of the periaqueductal gray-rostral ventromedial medullary circuit during the development of tolerance to morphine in the rat. Eur J Neurosci 27:1517-1524. CrossRef Medline

Loyd DR, Wang X, Murphy AZ (2008b) Sex differences in micro-opioid receptor expression in the rat midbrain periaqueductal gray are essential for eliciting sex differences in morphine analgesia. J Neurosci 28:1400714017. CrossRef Medline

Marinelli C, Di Liddo R, Facci L, Bertalot T, Conconi MT, Zusso M, Skaper SD, Giusti P (2015) Ligand engagement of Toll-like receptors regulates their expression in cortical microglia and astrocytes. J Neuroinflammation 12:244. CrossRef Medline

Mogil JS, Chesler EJ, Wilson SG, Juraska JM, Sternberg WF (2000) Sex differences in thermal nociception and morphine antinociception in rodents depend on genotype. Neurosci Biobehav Rev 24:375-389. CrossRef Medline

Morgan MM, Clayton CC, Boyer-Quick JS (2005) Differential susceptibility of the PAG and RVM to tolerance to the antinociceptive effect of morphine in the rat. Pain 113:91-98. CrossRef Medline

Morgan MM, Fossum EN, Stalding BM, King MM (2006) Morphine antinociceptive potency on chemical, mechanical, and thermal nociceptive tests in the rat. J Pain 7:358-366. Medline

Morrison HW, Filosa JA (2016) Sex differences in astrocyte and microglia responses immediately following middle cerebral artery occlusion in adult mice. Neuroscience 339:85-99. CrossRef Medline

Mousa SA (2003) Morphological correlates of immune-mediated peripheral opioid analgesia. Adv Exp Med Biol 521:77-87. Medline 
Murphy AZ, Suckow SK, Johns M, Traub RJ (2009) Sex differences in the activation of the spinoparabrachial circuit by visceral pain. Physiol Behav 97:205-212. CrossRef Medline

Murugan M, Sivakumar V, Lu J, Ling EA, Kaur C (2011) Expression of $\mathrm{N}$-methyl D-aspartate receptor subunits in amoeboid microglia mediates production of nitric oxide via NF-kappaB signaling pathway and oligodendrocyte cell death in hypoxic postnatal rats. Glia 59:521-539. CrossRef Medline

Nakamura Y, Si QS, Kataoka K (1999) Lipopolysaccharide-induced microglial activation in culture: temporal profiles of morphological change and release of cytokines and nitric oxide. Neurosci Res 35:95-100. CrossRef Medline

Nguyen KT, Deak T, Owens SM, Kohno T, Fleshner M, Watkins LR, Maier SF (1998) Exposure to acute stress induces brain interleukin-1beta protein in the rat. J Neurosci 18:2239-2246. Medline

Ogoshi F, Yin HZ, Kuppumbatti Y, Song B, Amindari S, Weiss JH (2005) Tumor necrosis-factor-alpha (TNF-alpha) induces rapid insertion of $\mathrm{Ca} 2+$-permeable alpha-amino-3-hydroxyl-5-methyl-4-isoxazole-propionate (AMPA)/kainate ( $\mathrm{Ca}-\mathrm{A} / \mathrm{K})$ channels in a subset of hippocampal pyramidal neurons. Exp Neurol 193:384-393. CrossRef Medline

Picker MJ, Daugherty D, Henry FE, Miller LL, Dykstra LA (2011) Metabotropic glutamate antagonists alone and in combination with morphine: comparison across two models of acute pain and a model of persistent, inflammatory pain. Behav Pharmacol 22:785-793. CrossRef Medline

Puehler W, Zöllner C, Brack A, Shaqura MA, Krause H, Schäfer M, Stein C (2004) Rapid upregulation of mu opioid receptor mRNA in dorsal root ganglia in response to peripheral inflammation depends on neuronal conduction. Neuroscience 129:473-479. CrossRef Medline

Qin L, Wu X, Block ML, Liu Y, Breese GR, Hong JS, Knapp DJ, Crews FT (2007) Systemic LPS causes chronic neuroinflammation and progressive neurodegeneration. Glia 55:453-462. CrossRef Medline

Quan N, Whiteside M, Herkenham M (1998) Time course and localization patterns of interleukin-1beta messenger RNA expression in brain and pituitary after peripheral administration of lipopolysaccharide. Neuroscience 83:281-293. CrossRef Medline

Quan N, Stern EL, Whiteside MB, Herkenham M (1999) Induction of proinflammatory cytokine mRNAs in the brain after peripheral injection of subseptic doses of lipopolysaccharide in the rat. J Neuroimmunol 93:7280. CrossRef Medline

Roth J, De Souza GE (2001) Fever induction pathways: evidence from responses to systemic or local cytokine formation. Braz J Med Biol Res 34:301-314. CrossRef Medline

Roth J, Conn CA, Kluger MJ, Zeisberger E (1993) Kinetics of systemic and intrahypothalamic IL-6 and tumor necrosis factor during endotoxin fever in guinea pigs. Am J Physiol 265:R653-R658. Medline

Schneider CP, Schwacha MG, Chaudry IH (2006) Influence of gender and age on T-cell responses in a murine model of trauma-hemorrhage: differences between circulating and tissue-fixed cells. J Appl Physiol 100:826833. Medline

Schwarz JM, Bilbo SD (2012) Sex, glia, and development: interactions in health and disease. Horm Behav 62:243-253. CrossRef Medline

Song P, Zhao ZQ (2001) The involvement of glial cells in the development of morphine tolerance. Neurosci Res 39:281-286. CrossRef Medline
Sorge RE, et al. (2015) Different immune cells mediate mechanical pain hypersensitivity in male and female mice. Nat Neurosci 18:1081-1083. CrossRef Medline

Sorge RE, LaCroix-Fralish ML, Tuttle AH, Sotocinal SG, Austin JS, Ritchie J, Chanda ML, Graham AC, Topham L, Beggs S, Salter MW, Mogil JS (2011) Spinal cord Toll-like receptor 4 mediates inflammatory and neuropathic hypersensitivity in male but not female mice. J Neurosci 31: 15450-15454. CrossRef Medline

Stellwagen D, Beattie EC, Seo JY, Malenka RC (2005) Differential regulation of AMPA receptor and GABA receptor trafficking by tumor necrosis factor-alpha. J Neurosci 25:3219-3228. CrossRef Medline

Tanga FY, Nutile-McMenemy N, DeLeo JA (2005) The CNS role of Tolllike receptor 4 in innate neuroimmunity and painful neuropathy. Proc Natl Acad Sci U S A 102:5856-5861. CrossRef Medline

Thomas DM, Kuhn DM (2005) MK-801 and dextromethorphan block microglial activation and protect against methamphetamine-induced neurotoxicity. Brain Res 1050:190-198. CrossRef Medline

Tonelli LH, Holmes A, Postolache TT (2008) Intranasal immune challenge induces sex-dependent depressive-like behavior and cytokine expression in the brain. Neuropsychopharmacology 33:1038-1048. CrossRef Medline

Trescot AM, Boswell MV, Atluri SL, Hansen HC, Deer TR, Abdi S, Jasper JF, Singh V, Jordan AE, Johnson BW, Cicala RS, Dunbar EE, Helm S 2nd, Varley KG, Suchdev PK, Swicegood JR, Calodney AK, Ogoke BA, Minore WS, Manchikanti L (2006) Opioid guidelines in the management of chronic non-cancer pain. Pain Physician 9:1-39. Medline

Turrin NP, Gayle D, Ilyin SE, Flynn MC, Langhans W, Schwartz GJ, PlataSalamán CR (2001) Pro-inflammatory and anti-inflammatory cytokine mRNA induction in the periphery and brain following intraperitoneal administration of bacterial lipopolysaccharide. Brain Res Bull 54:443453. CrossRef Medline

Wang X, Traub RJ, Murphy AZ (2006) Persistent pain model reveals sex difference in morphine potency. Am J Physiol Reg Integ Comp Physiol 291:R300-R306. CrossRef Medline

Wang X, Loram LC, Ramos K, de Jesus AJ, Thomas J, Cheng K, Reddy A, Somogyi AA, Hutchinson MR, Watkins LR, Yin H (2012) Morphine activates neuroinflammation in a manner parallel to endotoxin. Proc Natl Acad Sci U S A 109:6325-6330. CrossRef Medline

Watkins LR, Hutchinson MR, Johnston IN, Maier SF (2005) Glia: novel counter-regulators of opioid analgesia. Trends Neurosci 28:661-669. CrossRef Medline

Whitacre CC (2001) Sex differences in autoimmune disease. Nat Immunol 2:777-780. CrossRef Medline

Whitacre CC, Reingold SC, O'Looney PA (1999) A gender gap in autoimmunity. Science 283:1277-1278. CrossRef Medline

Yan X, Yadav R, Gao M, Weng HR (2014) Interleukin-1 beta enhances endocytosis of glial glutamate transporters in the spinal dorsal horn through activating protein kinase C. Glia 62:1093-1109. CrossRef Medline

Zhang X, Zhang Y, Asgar J, Niu KY, Lee J, Lee KS, Schneider M, Ro JY (2014) Sex differences in mu-opioid receptor expression in trigeminal ganglia under a myositis condition in rats. Eur J Pain 18:151-161. CrossRef Medline 